\title{
Energy, Economic, and Environmental Benefits of the Solar America Initiative
}

Subcontract Report NREL/SR-640-41998

August 2007
S. Grover

ECONorthwest

Portland, Oregon
NREL is operated by Midwest Research Institute • Battelle

Contract No. DE-AC36-99-G010337

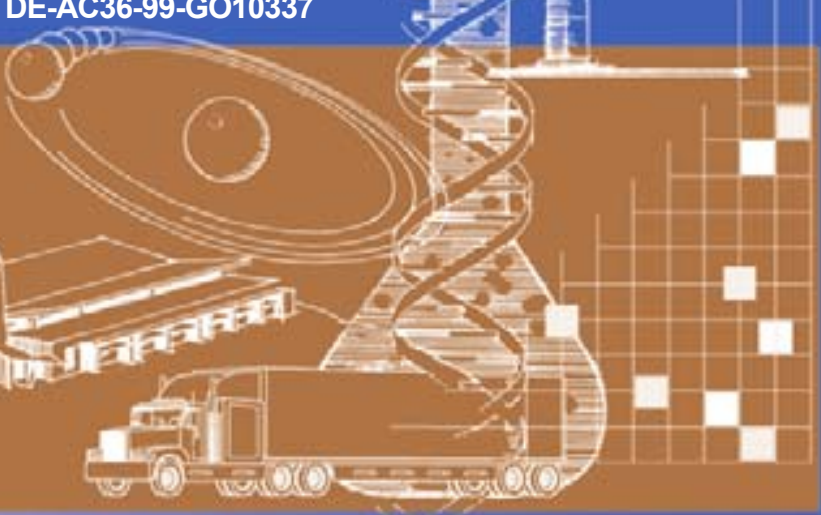


Energy, Economic, and Environmental Benefits of the Solar America Initiative

S. Grover

ECONorthwest

Portland, Oregon

NREL Technical Monitor: R. Margolis

Prepared under Subcontract No. ADJ-7-77253-01 


\section{NOTICE}

This report was prepared as an account of work sponsored by an agency of the United States government. Neither the United States government nor any agency thereof, nor any of their employees, makes any warranty, express or implied, or assumes any legal liability or responsibility for the accuracy, completeness, or usefulness of any information, apparatus, product, or process disclosed, or represents that its use would not infringe privately owned rights. Reference herein to any specific commercial product, process, or service by trade name, trademark, manufacturer, or otherwise does not necessarily constitute or imply its endorsement, recommendation, or favoring by the United States government or any agency thereof. The views and opinions of authors expressed herein do not necessarily state or reflect those of the United States government or any agency thereof.

Available electronically at http://www.osti.gov/bridge

Available for a processing fee to U.S. Department of Energy and its contractors, in paper, from:

U.S. Department of Energy

Office of Scientific and Technical Information

P.O. Box 62

Oak Ridge, TN 37831-0062

phone: 865.576 .8401

fax: 865.576 .5728

email: mailto:reports@adonis.osti.gov

Available for sale to the public, in paper, from:

U.S. Department of Commerce

National Technical Information Service

5285 Port Royal Road

Springfield, VA 22161

phone: 800.553 .6847

fax: 703.605.6900

email: orders@ntis.fedworld.gov

online ordering: http://www.ntis.gov/ordering.htm

This publication received minimal editorial review at NREL 


\section{Acknowledgments}

This report was prepared by ECONorthwest's Portland, OR office for the National Renewable Energy Laboratory. Dr. Stephen Grover was the project manager for the analysis and primary author of this report. Questions regarding the report should be directed to him by e-mail at grover@portland.econw.com or by phone at (503) 222-6060. ECONorthwest staff members John Boroski, Alec Josephson, Jonny Holz, Rob Wyman, and Jessica Brown assisted with the analysis and preparation of this report. 


\section{TABLE OF CONTENTS}

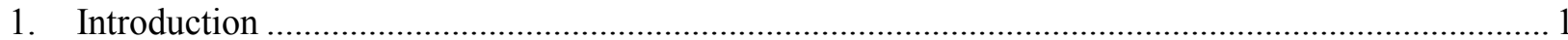

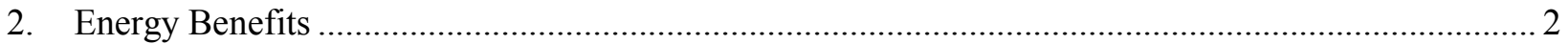

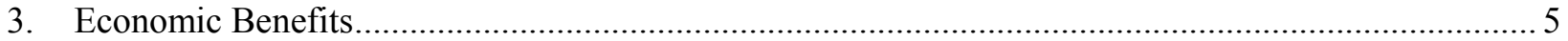

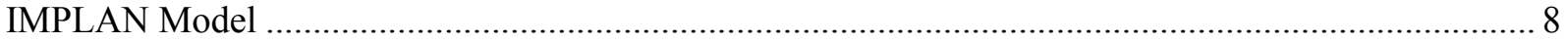

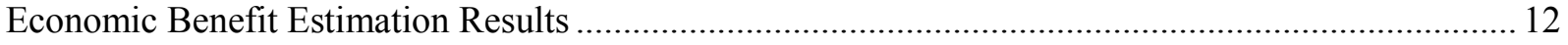

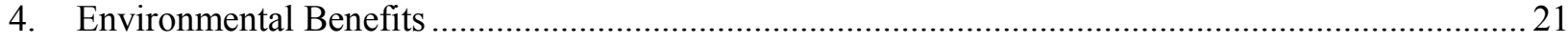

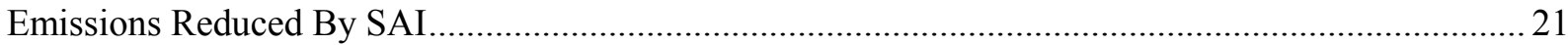

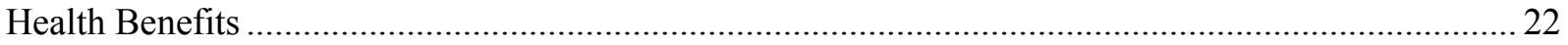

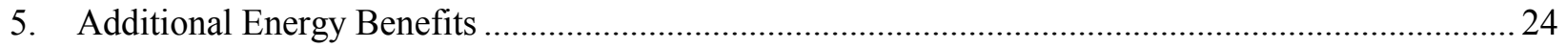

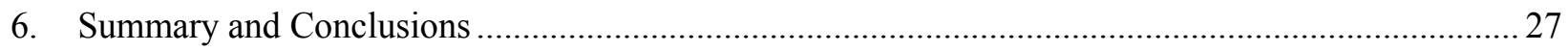

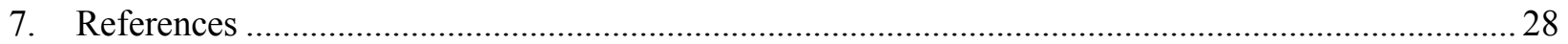

Appendix A: Detailed IMPLAN Model Results............................................................................ A-1

Appendix B: IMPLAN Model Technical Detail ................................................................................. B-1 


\section{INTRODUCTION}

The President's Solar America Initiative (SAI) was launched in January 2006 as part of the administration's Advanced Energy Initiative. The SAI is being led by the U. S. Department of Energy (DOE) Solar Energy Technologies Program (SETP), with the National Renewable Energy Laboratory (NREL) providing analytical and technical support. The SAI has a goal of installing 5-10 GW of photovoltaic (PV) systems in the U.S. by 2015 and 70-100 GW of PV systems in the U.S. by 2030. To make PV cost competitive with other energy resources, this requires that the installed cost of PV fall from approximately $\$ 8 / \mathrm{Wdc}$ in 2005 to $\$ 3.3 / \mathrm{Wdc}$ in 2015 and $\$ 2.5 / \mathrm{Wdc}$ in 2030 .

This report presents estimates of the potential benefits should the SAI PV installation goals be achieved. For this analysis, the areas researched include energy, economic, and environmental benefits. For the purposes of estimating these benefits, we assume that the SAI meets its PV installation goals. Other issues - such as estimating consumer demand for solar and determining the optimal market mechanism that will drive installation cost reductions - are important, but outside the scope of this project.

Throughout this report, benefits are calculated for both high and low scenarios for the SAI goals based on the target installation costs and amount of PV installed:

- The Low Scenario assumes that $5 \mathrm{GW}$ of PV is installed by 2015 at $\$ 3.3 / \mathrm{Wdc}$ and $70 \mathrm{GW}$ is installed by 2030 at $\$ 2.5 / \mathrm{Wdc}$

- The High Scenario assumes that $10 \mathrm{GW}$ of PV is installed by 2015 at $\$ 3.3 / \mathrm{Wdc}$ and $100 \mathrm{GW}$ of solar is installed by 2030 at $\$ 2.5 / \mathrm{Wdc}$.

To estimate the potential SAI benefits given these scenarios, ECONorthwest completed the following:

- The IMPLAN input-output model was used to estimate the economic impacts associated with the manufacture, installation, and operation of PV systems that would meet the SAI installation goals

- Existing model results and secondary research findings were used to estimate emissions and associated health benefits that will result with PV installations

- Benefit factors taken from secondary sources were used to estimate additional environmental and energy benefits created by the SAI.

The remainder of this report is organized as follows. The Energy Benefits section provides an estimate of the amount of electricity generation that will be provided by the SAI if its goals are met as well as estimates of the amount of natural gas displaced. Following this, the Economic Benefits section presents estimates of the economic benefits assuming that the SAI installation goals are achieved and builds on the energy results provided in the previous section. The Environmental Benefits section presents a discussion of environmental benefits and includes emissions reductions and health benefits that could be achieved with PV installations that meet the SAI goals. This is followed by an Additional Benefits section that presents additional information on energy-related benefits that will result from the SAI, including information on possible additional energy benefits such as blackout prevention, price effects, emergency power, and reduced transmission and distribution (T\&D) losses. Finally, all of the estimated benefits are summarized in the Summary and Conclusions section. Additional IMPLAN model results are included in Appendix $A$ and a technical discussion of the IMPLAN model is included in Appendix $B$. 


\section{ENERGY BENEFITS}

Achieving the SAI goals for PV installation will result in a significant amount of electricity generation resources that will displace generation from more traditional sources. The first step in estimating the benefits of the SAI is to determine the amount of electricity generation that will result in both the high and low scenarios. The PV energy estimates are then used to determine the economic and environmental benefits in subsequent sections of this report.

Table 1 shows the estimated annual PV electricity generation that would result if the SAI achieved its PV installation goals in both the high and low scenarios. These results are based on an average annual solar capacity factor of 19 percent estimated by NREL based on national solar insolation data ${ }^{1}$. Actual insolation levels will vary based on location or orientation. In comparison, the Energy Information Administration (EIA) reports that in 2004, 397 MW of PV capacity was installed throughout the country, producing 579,000 annual MWh, for a capacity factor of approximately 17 percent $^{2}$.

Based on these assumptions, the SAI is projected to produce 10-20 TWh/yr of PV electricity generation in 2015 and 110-170 TWh/yr in 2030 based on the installed PV capacity in the high and low case scenarios. The EIA projects total U.S. electricity generation to be 4,713 TWh/yr in 2015 and 5,788 $\mathrm{TWh} / \mathrm{yr}$ in $2030^{3}$. Attaining the SAI targets would therefore result in PV displacing approximately $0.2-$ 0.4 percent of total U.S. electrical generation in 2015 and 2-3 percent of total generation in 2030. In terms of residential use, the EIA's Residential Energy Consumption Survey indicates that average U.S. household electricity consumption is about 10,000 kWh/yr (EIA 2001). Under the SAI, PV would therefore generate enough electricity to power 1-2 million homes in 2015 and 10-20 million homes in 2030.

Table 1: Estimated SAI PV Generation and Total U.S. Electricity Generation

\begin{tabular}{lcccc}
\hline \multicolumn{1}{c}{ Scenario } & $\begin{array}{c}\text { Installed PV } \\
\text { Capacity (GW) }\end{array}$ & $\begin{array}{c}\text { PV Generation } \\
\text { (TWh/yr) }\end{array}$ & $\begin{array}{c}\text { Total U.S. } \\
\text { Generation (TWh/yr) }\end{array}$ & $\begin{array}{c}\text { PV Percent of } \\
\text { Total Generation }\end{array}$ \\
\hline $\mathbf{2 0 1 5}$ Low & 5 & 8.3 & 4,713 & $0.2 \%$ \\
$\mathbf{2 0 1 5}$ High & 10 & 16.6 & 4,713 & $0.4 \%$ \\
$\mathbf{2 0 3 0}$ Low & 70 & 116.5 & 5,788 & $2.0 \%$ \\
$\mathbf{2 0 3 0}$ High & 100 & 166.4 & 5,788 & $2.9 \%$ \\
\hline
\end{tabular}

\section{Natural Gas Displaced}

One of the primary benefits of the SAI will be the displacement of natural gas used to generate electricity. PV generation is well suited to offset a portion of peak electricity demand, which is often met by natural gas power plants, as PV output is highly correlated with peak demand on the electricity system.

\footnotetext{
${ }^{1}$ Margolis (2006) bases this analysis of location-specific capacity factors from NREL's PVWatts PV simulation program available at: http://rredc.nrel.gov/solar/codes algs/PVWATTS/version1/.

${ }^{2}$ EIA Renewable Energy Annual 2004. Tables 11 and 12.

${ }^{3}$ EIA Annual Energy Outlook 2007 (Early Release) Data for Figure 5 available at: http://www.eia.doe.gov/oiaf/aeo/electricity.html
} 
Natural gas fuel savings were estimated for each of the SAI capacity scenarios using the following assumptions:

1. At relatively low penetration levels (less than 10 percent of total electricity generation), PV would displace fossil fuel generation on a one-to-one basis (Denholm and Margolis 2006).

2. Transmission and distribution (T\&D) losses for fossil fuel generation are assumed to average about 7 percent based on several studies reviewed for this report. This reflects electricity that is lost as it travels through the wires from generating plants to end-users. Due to these losses, fossil fuel plants must generate 7 percent more electricity than PV systems to provide end-users with an equivalent amount of electricity.

3. Seventy-five percent of the PV generation would displace natural gas generation, as estimated by Connors et al. (2005) in a recent analysis of the load-shape following characteristics of the U.S. electricity generation system. (The other 25 percent of PV generation would mainly displace coal generation.)

4. The average heat rate for all natural gas plants offset by PV generation is estimated to be 7,100 $\mathrm{BTU} / \mathrm{kWh}$ in future years ${ }^{4}$. Heat rates for natural gas plants vary greatly and depend on the type and vintage of the plant. While a typical natural gas combustion turbine (NGCT) has a heat rate of $11,100 \mathrm{BTU} / \mathrm{kWh}$, new natural gas combined cycle (NGCC) plants in California have a much lower heat rate of 7,100 BTU/kWh (Margolis 2006). The EIA expects the heat rate of new NGCC plants to continue to decline over time, to as low as $6,333 \mathrm{BTU} / \mathrm{kWh}$ in $2015^{5}$. Since natural gas offset by PV will be from a mix of old and new NGCC and NGCT plants, an average heat rate of $7,100 \mathrm{BTU} / \mathrm{kWh}$ is assumed for this analysis.

Based on these assumptions, the projected natural gas savings under the SAI are roughly $0.05-0.1$ quadrillion BTU (quads) in 2015 and $0.5-1.0$ quads in 2030. The EIA projects that total U.S. natural gas consumption will be 26 quads in 2015 and 27 quads in $2030 .{ }^{6}$ Thus, PV generation due to the SAI is expected to displace $0.2-0.4$ percent of natural gas consumption in 2015 and 2-4 percent of natural gas consumption in 2030.

Another way to view the benefits of reduced natural gas consumption is to consider the potential impact on liquefied natural gas (LNG) imports. LNG imports to the U.S. increased 700 percent between 1997 and 2005, and much of this demand has been driven by increased natural gas consumption for electricity generation. ${ }^{7}$ During this same period, natural gas use for electricity generation increased by 1.8 quads (43 percent).

In the future, increasing use of natural gas use for electricity generation is expected to drive further increases in LNG imports. LNG imports are projected to rise from approximately 0.5 quads in 2003 to 3 quads in 2015 and to 4 quads in $2030^{8}$. By offsetting a significant amount of natural gas generation, the

\footnotetext{
${ }^{4}$ The heat conversion rate provides a measure of thermal efficiency (BTU per kWh) for converting heat input to electricity output.

${ }^{5}$ EIA Annual Energy Outlook 2006.

${ }^{6}$ EIA Annual Energy Outlook 2007 (Early Release) Data for Figure 3 available at: http://www.eia.doe.gov/oiaf/aeo/consumption.html

${ }^{7}$ EIA. Natural Gas: U.S. Data. Available at: www.eia.doe.gov/oil_gas/natural_gas/info_glance/natural_gas.html.

${ }^{8}$ Ibid.
} 
SAI could displace the equivalent of 2-3 percent of LNG imports by 2015 and 12-24 percent of LNG imports by 2030 .

\section{Natural Gas Plants Avoided}

Since the SAI will result in PV installations that help provide electricity during peak demand periods, the need for constructing new natural gas peaking plants will be reduced. The following assumptions were used to determine the number of new natural gas plants avoided due to the SAI:

1. The average effective load carrying capacity (ELCC) of PV was assumed to be 60 percent (i.e., on average, 60 percent of installed PV capacity is available during peak generation periods) based on research by Perez et al (2006). Thus, each $1 \mathrm{GW}$ of PV would displace the need for $0.6 \mathrm{GW}$ of natural gas peaking generation capacity.

2. On average, new natural gas plants will be sized at $250 \mathrm{MW}$ in the future. EIA data indicates that over the next few years, utilities plan to build natural gas plants in the 170-215 MW size range 9 . After that, the EIA projects that typical new plant sizes will continue to grow ${ }^{10}$.

Under the SAI scenarios, PV systems would eliminate the need for 3-6 GW of new gas generating capacity through 2015 and 42-61 GW of new capacity through 2030 . EIA projects that $48 \mathrm{GW}$ of new natural gas electricity generation capacity will be required between 2005 and 2015, and $124 \mathrm{GW}$ of new natural gas electricity generation capacity will be required between 2005 and $2030 .{ }^{11}$ Given the forecasted demand, the estimated PV installations would be the equivalent of 6-13 percent of projected new natural gas capacity between 2005 and 2015, and 34-49 percent of new natural gas capacity between 2005 and 2030. Stated differently, attaining the SAI goals would avoid the construction of 12-24 natural gas plants by 2015 and $170-240$ plants by 2030 .

The following section uses these energy results to estimate the potential economic benefits should the SAI goals be achieved.

\footnotetext{
${ }^{9}$ EIA Electric Power Annual 2004. Table 2.5

${ }^{10}$ EIA Annual Energy Outlook 2006.

${ }^{11}$ Ibid.
} 


\section{ECONOMIC BENEFITS}

Achieving the SAI's installation goals will stimulate a significant amount of economic activities as resources are directed toward solar-related industries. This activity will be offset to some degree by decreased economic activity in other sectors, however, as the new PV resources displace more conventional power sources.

The gross impacts of the SAI only account for activities related to PV construction, installation and maintenance, and do not consider the forgone spending in other energy sectors. For this analysis, ECONorthwest also compared the estimated impacts of the SAI to a counterfactual scenario in which most of the electricity that would be generated by PV is instead assumed to be provided by natural gas plants. The difference in economic impacts between the SAI scenario and the counterfactual scenario is referred to as the net impact of the SAI. For example, if a net impact of 100 new jobs is reported, this means that the SAI would result in 100 more jobs than would have occurred relative to the case where the SAI is not achieved and electricity is provided instead by natural gas generation. Both the gross and net impacts of the SAI are described in this section of the report.

\section{SCENARIO ASSUMPTIONS}

As with the energy benefits described in the previous section, the economic benefits were estimated using both a high and low scenario derived from the SAI goals:

- The Low Scenario assumes that $5 \mathrm{GW}$ of PV is installed by 2015 at $\$ 3.3 / \mathrm{Wdc}$ and $70 \mathrm{GW}$ is installed by 2030 at $\$ 2.5 / \mathrm{Wdc}$

- The High Scenario assumes that $10 \mathrm{GW}$ of PV is installed by 2015 at $\$ 3.3 / \mathrm{Wdc}$ and $100 \mathrm{GW}$ of solar is installed by 2030 at $\$ 2.5 / \mathrm{Wdc}$.

The energy benefits described in the last section were also used in the economic analysis for both the high and low scenarios.

The first step in estimating the economic impacts of the SAI is to determine the manufacturing and O\&M costs (expenditures) associated with installing the new PV capacity. Table 2 summarizes the construction and O\&M costs for $1 \mathrm{MW}$ of PV installed at the different price points assumed for $2015(\$ 3.3 / \mathrm{Wdc})$ and $2030(\$ 2.5 / \mathrm{Wdc})$, and these costs are used as inputs into the estimation of economic benefits. PV costs are allocated as 70 percent in manufacture and 30 percent in installation. ${ }^{12}$ This allocation remains fixed but the total system cost decreases over time as both the manufacturing and installation costs are assumed to decrease proportionately with price. PV maintenance costs are also assumed to decrease in direct proportion to system costs, decreasing from $\$ 35 / \mathrm{kW}$ in 2005 to $\$ 10.94 / \mathrm{kW}$ in $2030 .{ }^{13}$

\footnotetext{
${ }^{12}$ Installation costs also include design, site preparation, permitting, and other soft costs. Cost allocation based on information included in Solar Energy Technologies Program Multi-Year Program Plan 2007-2011. U.S. Department of Energy. Department of Energy Efficiency and Renewable Energy. 2006.

${ }^{13}$ Based on 2005 annual O\&M costs of $\$ 42 / \mathrm{kW}$ for residential systems and $\$ 28 / \mathrm{kW}$ for commercial systems; $\$ 35 / \mathrm{kW}$ is the average of these values. Ibid.
} 
Table 2: PV Installation and O\&M Cost Assumptions

\begin{tabular}{|c|c|c|}
\hline Cost Component & $\begin{array}{c}1 \mathrm{MW} \\
\$ 3.30 / \mathrm{Wdc} \\
2015\end{array}$ & $\begin{array}{c}1 \mathrm{MW} \\
\$ 2.50 / \mathrm{Wdc} \\
2030 \\
\end{array}$ \\
\hline PV Manufacture (70\%) & $\$ 2,310,000$ & $\$ 1,750,000$ \\
\hline PV Installation (30\%) & $\$ 990,000$ & $\$ 750,000$ \\
\hline $\begin{array}{l}\text { PV O\&M ( } \$ 35 \text { decreasing to } \\
\$ 10.94 / \mathrm{kW} \text { annually) }\end{array}$ & $\$ 14,440$ & $\$ 10,940$ \\
\hline
\end{tabular}

For each scenario, the economic benefits are grouped into three distinct categories based on spending activity:

- Construction benefits include both the manufacture and installation of PV systems

- Operations and Maintenance $(O \& M)$ refer to maintenance costs plus the energy savings that result from the PV systems

- Research and Development $(R \& D)$ refers to the benefits resulting from that portion of the annual SAI budget that is spent on research through private (non-governmental) research agencies.

Table 3 below shows the key assumptions for the SAI and counterfactual scenarios as they pertain to each of these activity areas.

Table 3: SAI Scenario and Counterfactual Assumptions

\begin{tabular}{lll}
\hline \multicolumn{1}{c}{ Activity } & \multicolumn{1}{c}{ SAI Assumption } & \multicolumn{1}{c}{ Counterfactual Assumption } \\
\hline Construction & $\begin{array}{l}\text { Dollars spent on PV manufacture } \\
\text { and installation. }\end{array}$ & $\begin{array}{l}\text { Equivalent } \$ \text { spending on natural gas plant } \\
\text { construction (based on } 60 \% \text { assumed ELCC), with } \\
\text { remainder spent on household goods and } \\
\text { services. }\end{array}$ \\
& $\begin{array}{l}\text { \$35 to } \$ 10.94 / \mathrm{kW} \text { annual cost for } \\
\text { PV maintenance. Households } \\
\text { receive } \$ 0.097 / \mathrm{kWh} \text { in savings for } \\
\text { PV generation. }\end{array}$ & $\begin{array}{l}\text { Utilities lose } \$ 0.097 \text { in revenue for every } \mathrm{kWh} \\
\text { generated from PV. }\end{array}$ \\
& $\begin{array}{l}\text { 50\% of annual SAI budget goes to } \\
\text { private sector research. }\end{array}$ & $\begin{array}{l}\text { R\&D dollars spent on other Federal government } \\
\text { programs. }\end{array}$ \\
\hline
\end{tabular}

Additional assumptions are shown in Table 4 and all values are reported as 2007 dollars. Natural gas construction costs are set at $\$ 0.67 / \mathrm{Wdc}$ and do not vary over time. The O\&M costs for natural gas plants are included in the retail price of electricity sold from these plants. For this analysis we assume that the retail price does not change over time (other than for inflation) in order to develop a conservative estimate of economic benefits. The effect of relaxing this assumption and allowing for price increases is discussed later in this report. 
To convert the installed capacity of the PV systems to a natural gas $\mathrm{kWh}$ value, the same parameter assumptions are used that were discussed in the preceding Energy Benefits section of this report. To determine the amount of PV power generated, we apply a capacity factor of 19 percent based on average solar insolation in the United States. Given a 19 percent capacity factor, $1 \mathrm{GW}$ of PV is assumed to produce 1,664 GWh of electricity annually. The kWh produced by PV is assumed to offset electricity purchased from utilities on a one-to-one basis (after adjusting for T\&D losses). We also assume a 60 percent ELCC in our calculations to determine the amount of power generation offset by the SAI installations.

Finally, in the economic benefit calculations, the electricity bill savings are all allocated to household spending even though some of the PV systems will likely be installed in the commercial sector. This is done under the assumption that any savings achieved in the commercial sector will eventually be passed on through to households through lower prices. It also simplifies the input-output modeling, as we do not need to identify which specific commercial sectors will install solar. ${ }^{14}$

Table 4: Natural Gas Plant and Generation Assumptions

\begin{tabular}{lll}
\hline \multicolumn{1}{c}{ Assumption } & Value & \multicolumn{1}{c}{ Source } \\
\hline Natural Gas Plant Construction Cost & $\$ 0.67 / \mathrm{Wdc}$ & $\begin{array}{l}\text { University of Chicago study on nuclear } \\
\text { power (2004), adjusted to 2007 \$. }\end{array}$ \\
PV Capacity Factor & 19 percent & $\begin{array}{l}\text { Provided by NREL based on location- } \\
\text { specific capacity factors used in the PV Watts } \\
\text { simulation program }\end{array}$ \\
Transmission \& Distribution Loss Factor & 7 percent & $\begin{array}{l}\text { Average based on U.S. Climate Change } \\
\text { Technology Program (2003) and Connors et. } \\
\text { al. (2005) }\end{array}$ \\
PV Effective Load Carrying Capacity & 60 percent & $\begin{array}{l}\text { Perez et. al. (2006) } \\
\text { Electricity Price }\end{array}$ \\
\hline
\end{tabular}

For the construction impacts, a numerical example will help illustrate how the net impacts were calculated. In the analysis, solar installations are assumed to have an effective load carrying capacity (ELCC) of 60 percent relative to a new natural gas plant. That is, every gigawatt installed reduces the need to construct $600 \mathrm{MW}$ of natural gas generating resources. A $1 \mathrm{GW}$ PV plant at $\$ 3.5 / \mathrm{Wdc}$ would cost $\$ 3.5$ billion and displace the need to build $600 \mathrm{MW}$ of natural gas generation at a cost of $\$ 402$ million (600 MW@ @0.67/Wdc). Since the natural gas plant costs less than the PV installations, the remaining portion ( $\$ 3.1$ billion) needs to be accounted for in the input-output model so that both scenarios assume

\footnotetext{
${ }^{14}$ Different commercial sectors will have potentially significant differences in benefits from PV depending on the energy intensity of that industry. Efforts to capture these effects on production efficiencies (and subsequent results on production costs and retail prices of goods) requires the use of more sophisticated general equilibrium models rather than the static IMPLAN model. Because the potential production gains through PV are omitted from this analysis, the economic benefit estimates should be considered conservative.
} 
total spending of $\$ 3.5$ billion. In the counterfactual scenario, we assume that the remaining $\$ 3.1$ billion is spent by U.S. households following historical purchase patterns.

In this example, assume that the PV spending results in 15,000 jobs while spending in the natural gas counterfactual scenario results in 12,000 jobs. In this case, the net impact of the PV installations is the difference between the two scenarios, or 3,000 jobs $(15,000-12,000)$.

Presenting the economic impacts in terms of net benefits results in numbers that are-by definitionlower than gross impact values, and in many cases lower than the gross impacts that have been reported in other studies. For example, the 2001 study The Work That Goes Into Renewable Energy published by the Renewable Energy Policy Project (REPP) found that there are approximately 35 jobs associated with the manufacture and installation of $1 \mathrm{MW}$ of PV. We used these numbers to help develop the PV cost input values for our analysis. However, the final net benefit results reported here are lower than the REPP results, as they incorporate the natural gas counterfactual scenario presented above. In contrast, the REPP study did not incorporate any counterfactual information, and therefore the employment figures from that report reflect gross rather than net employment effects.

\section{IMPLAN MODEL}

The IMPLAN input-output model is used to estimate the SAI economic benefits based on the assumptions described above. Input-output analysis employs specific terminology to identify the different types of economic impacts resulting from economic activities. Expenditures made as a result of the SAI affect the U.S. economy directly, through domestic purchases of goods and services, and indirectly, as those purchases, in turn, generate purchases of intermediate goods and services from other, related sectors of the economy. In addition, the direct and indirect increases in employment and income enhance overall economy purchasing power, thereby inducing further consumption- and investment- driven stimulus. This cycle continues until the spending eventually leaks out of the U.S. economy as a result of taxes, savings, or purchases of non-locally produced goods and services or "imports." Throughout this report, results are presented for the direct, indirect, and induced effects described above.

Within this overall framework, the IMPLAN model reports the following economic impacts:

- Output is the value of production by industries for a specified period of time. Output can be also thought of as the value of sales including reductions or increases in business inventories.

- Personal Income represents the total payments to workers (wages) and business owners (proprietor and corporate income). Together, wages and business income are often referred to as personal income. Corporate income represents net business income or profits. These may be reinvested or paid as dividends to shareholders. Income excludes payments from one industry to another for the purchase of intermediate goods, and is often used as a measure of the value added during production. ${ }^{15}$

- Job impacts include both full and part time employment.

- $\quad$ Tax revenues for various state and local taxing jurisdictions.

\footnotetext{
${ }^{15}$ Alternatively, value added is measured as total output less purchases of intermediate goods and services. In either case, the measure of value added will be the same. However, to the extent that owners of corporations live outside the relevant study area, including corporate income will tend to overestimate the measure of value added in production.
} 
The results for Output, Personal Income, and Jobs are presented in the main body of the report while detailed for these categories plus Tax Revenues are included in Appendix A. Additional technical detail on the IMPLAN model is provided in Appendix B.

\section{GROSS ECONOMIC BENEFITS}

This section describes the gross economic benefits that could be expected from the SAI, and does not take into account the changes in economic activity that would have occurred in other sectors (e.g., due to natural gas plant construction) if the goals of the SAI were not achieved. The tables in this section present selected analysis results from the input-output model runs. To keep the results to a manageable level, only selected years (2015 and 2030) are reported in the main report for both the high and low scenarios. For each year, the results for the construction, O\&M, and R\&D activities are reported.

Note that NREL assumes that $1 \mathrm{GW}$ of PV capacity will likely be installed by 2015, and that 15 to 20 GW of PV capacity will be installed by 2030 even without the SAI. In this report, only the new PV installations that are caused by the SAI are used to calculate the economic impacts. In Table 5 (and all subsequent tables), a column labeled "Total Installed Capacity" shows the total PV installations for a particular year and includes capacity that is expected as part of the baseline. A second column labeled "SAI Induced Annual Installed Capacity" reflects only the PV installations that are assumed to result directly from the SAI. It is the capacity shown in this second column that is used to calculate the economic benefits shown in the rest of the table.

Table 5 shows the gross benefits of the PV system construction (manufacture and installation) for 2015. Again, these results do not adjust for impacts that would have otherwise occurred in the counterfactual scenario, which assumes natural gas plant construction. The construction results reflect the impacts that occur only during the construction period, which is assumed to be a single year.

For the high scenario, a cumulative total of $10 \mathrm{GW}$ of new PV is installed by 2015 . This construction will result in a gross increase in economic output of $\$ 27$ billion during the construction period. This will also result in a gross increase in personal income of $\$ 8.7$ billion over the same period, and total full-time and part-time jobs would increase by 162,890 .

The bottom of Table 5 shows the same gross results in the construction phase assuming the low scenario of $5 \mathrm{GW}$ of installed PV by 2015. In the low scenario, the SAI results in a gross increase of economic output of $\$ 8.2$ billion and a gross increase in personal income of $\$ 2.6$ billion. This also results in a gross increase in jobs of 49,370 .

Table 5: Annual Gross Construction Impacts (2015)

\begin{tabular}{lcccccc}
\hline $\begin{array}{c}\text { Construction Gross } \\
\text { Impacts }\end{array}$ & $\begin{array}{c}\text { Total Annual } \\
\text { Installed } \\
\text { Capacity In 2015 }\end{array}$ & $\begin{array}{c}\text { SAI Induced } \\
\text { Annual Installed } \\
\text { Capacity In 2015 }\end{array}$ & Direct & Indirect & Induced & Total \\
\hline \multicolumn{1}{c}{ High Scenario } & 2.74 & 2.37 & $\$ 7,989,362,000$ & $\$ 9,024,295,000$ & $\$ 10,087,769,000$ & $\$ 27,101,426,000$ \\
Output & 2.74 & 2.37 & $\$ 2,486,000,000$ & $\$ 3,056,905,000$ & $\$ 3,158,265,000$ & $\$ 8,701,170,000$ \\
Personal Income & 2.74 & 2.37 & 36,500 & 51,440 & 74,950 & 162,890 \\
Jobs & 1.02 & 0.72 & $\$ 2,421,746,000$ & $\$ 2,735,456,000$ & $\$ 3,057,818,000$ & $\$ 8,215,020,000$ \\
\hline \multicolumn{1}{c}{ Low Scenario } & 1.02 & 0.72 & $\$ 753,560,000$ & $\$ 926,613,000$ & $\$ 957,337,000$ & $\$ 2,637,510,000$ \\
Output & 1.02 & 0.72 & 11,060 & 15,590 & 22,720 & 49,370 \\
Personal Income & & & & & & \\
Jobs & & & & & & \\
\hline
\end{tabular}

Table 6 shows the gross impacts of PV O\&M activities in 2015 for both the high and low SAI scenarios. The O\&M impacts account for maintenance costs as well as money saved on electricity bills due to the PV systems. For the high scenario, O\&M activities result in a gross increase in total economic output of 
\$3.6 billion annually based on the $10 \mathrm{GW}$ of installed PV capacity. Personal income also shows a gross increase of over $\$ 1.1$ billion annually and an additional 27,510 jobs are added due to the SAI in 2015 .

The low scenario results are also shown in Table 6 for 2015. Since the low scenario is based on half of the installed PV capacity ( $5 \mathrm{GW}$ rather than $10 \mathrm{GW}$ in 2015), the economic impacts are also reduced by 50 percent relative to the high scenario, with slight differences due to rounding.

Table 6: Cumulative Gross O\&M Impacts (2015)

\begin{tabular}{|c|c|c|c|c|c|c|}
\hline O\&M Gross Impacts & $\begin{array}{c}\text { Total } \\
\text { Cummulative } \\
\text { Installed } \\
\text { Capacity in } 2015\end{array}$ & $\begin{array}{c}\text { SAI Induced } \\
\text { Cummulative } \\
\text { Installed } \\
\text { Capacity in } 2015\end{array}$ & Direct & Indirect & Induced & Total \\
\hline \multicolumn{7}{|l|}{ High Scenario } \\
\hline Output & 10.00 & 9.00 & $\$ 1,399,807,000$ & $\$ 961,320,000$ & $\$ 1,301,392,000$ & $\$ 3,662,519,000$ \\
\hline Personal Income & 10.00 & 9.00 & $\$ 453,592,000$ & $\$ 302,021,000$ & $\$ 407,449,000$ & $\$ 1,163,062,000$ \\
\hline Jobs & 10.00 & 9.00 & 11,860 & 5,980 & 9,670 & 27,510 \\
\hline \multicolumn{7}{|l|}{ Low Scenario } \\
\hline Output & 5.00 & 4.00 & $\$ 622,136,000$ & $\$ 427,253,000$ & $\$ 578,397,000$ & $\$ 1,627,786,000$ \\
\hline Personal Income & 5.00 & 4.00 & $\$ 201,596,000$ & $\$ 134,232,000$ & $\$ 181,089,000$ & $\$ 516,917,000$ \\
\hline Jobs & 5.00 & 4.00 & 5,270 & 2,660 & 4,300 & 12,230 \\
\hline
\end{tabular}

Note: Table shows annual impacts in 2015 based on cumulative SAI PV installations.

The gross economic impacts resulting from the SAI R\&D funding are shown in Table 7 and are based on the annual funding of $\$ 148$ million. Of this budget, 50 percent is assumed to go to private research entities in the U.S. Funding is assumed to be constant between the high and low scenarios. The spending on solar R\&D through the SAI results in a gross increase in economic output of $\$ 235$ million with personal income increasing by $\$ 101$ million. The $R \& D$ funding also results in a gross increase of 1,780 jobs.

Table 7: Annual Gross R\&D Impacts (2015)

\begin{tabular}{lccccc}
\hline R\&D Gross Impacts & $\begin{array}{c}\text { Annual R\&D } \\
\text { Spending }\end{array}$ & Direct & Indirect & Induced & Total \\
\hline \multicolumn{1}{c}{ High Scenario } & $\$ 148,000,000$ & & & & \\
Output & & $\$ 73,634,000$ & $\$ 47,076,000$ & $\$ 114,377,000$ & $\$ 235,087,000$ \\
Personal Income & & $\$ 48,979,000$ & $\$ 16,121,000$ & $\$ 35,809,000$ & $\$ 100,909,000$ \\
R\&D Impacts - Gross & & 600 & 330 & 850 & 1,780 \\
\hline \multicolumn{1}{c}{ Low Scenario } & $\$ 148,000,000$ & & & & \\
Output & & $\$ 73,634,000$ & $\$ 47,076,000$ & $\$ 114,377,000$ & $\$ 235,087,000$ \\
Personal Income & & $\$ 48,979,000$ & $\$ 16,121,000$ & $\$ 35,809,000$ & $\$ 100,909,000$ \\
Jobs & & 600 & 330 & 850 & 1,780 \\
\hline
\end{tabular}

The combined gross economic benefits for 2015 across all activities are shown in Table 8. Additional detail on individual years is provided in Appendix A. 
Table 8: Gross Economic Benefit Summary (2015)

\begin{tabular}{|c|c|c|c|c|}
\hline $\begin{array}{c}\text { Economic Benefit } \\
\text { Category (Gross } \\
\text { Impacts) }\end{array}$ & Construction & O\&M & R\&D & Total \\
\hline \multicolumn{5}{|l|}{2015 High Scenario } \\
\hline Output & $\$ 27,101,426,000$ & $\$ 3,662,519,000$ & $\$ 235,087,000$ & $\$ 30,999,032,000$ \\
\hline Personal Income & $\$ 8,701,170,000$ & $\$ 1,163,062,000$ & $\$ 100,909,000$ & $\$ 9,965,141,000$ \\
\hline Jobs & 162,890 & 27,510 & 1,780 & 192,180 \\
\hline \multicolumn{5}{|l|}{2015 Low Scenario } \\
\hline Output & $\$ 8,215,020,000$ & $\$ 1,627,786,000$ & $\$ 235,087,000$ & $\$ 10,077,893,000$ \\
\hline Personal Income & $\$ 2,637,510,000$ & $\$ 516,917,000$ & $\$ 100,909,000$ & $\$ 3,255,336,000$ \\
\hline Jobs & 49,370 & 12,230 & 1,780 & 63,380 \\
\hline
\end{tabular}

Table 9 shows the annual gross construction impacts for 2030 for both the high and low SAI scenarios and assumes that PV costs have fallen to $\$ 2.5 / \mathrm{Wdc}$. For the high scenario, a cumulative total of $100 \mathrm{GW}$ of new PV is installed by 2030 . This construction results in a gross increase of over $\$ 67$ billion in economic output and personal income has a gross increase of $\$ 21.5$ billion. The PV construction activity also results in a gross increase of 403,920 jobs in 2030.

The low scenario construction impacts are greater than the high scenario impacts, as the low scenario installs more capacity in the last year of construction (2030) compared to the high scenario, and construction impacts are shown for a single year. In the low scenario for 2030, output increases by almost $\$ 73$ billion, personal income increases by $\$ 23.4$ billion, and jobs show a gross increase of $438,690 .{ }^{16}$

Table 9: Annual Gross Construction Impacts (2030)

\begin{tabular}{|c|c|c|c|c|c|c|}
\hline $\begin{array}{l}\text { Construction Gross } \\
\text { Impacts }\end{array}$ & $\begin{array}{c}\text { Total Annual } \\
\text { Installed } \\
\text { Capacity In } 2030\end{array}$ & $\begin{array}{c}\text { SAI Induced } \\
\text { Annual Installed } \\
\text { Capacity In } 2030\end{array}$ & Direct & Indirect & Induced & Total \\
\hline \multicolumn{7}{|l|}{ High Scenario } \\
\hline Output & 10.40 & 7.77 & $\$ 19,810,956,000$ & $\$ 22,377,245,000$ & $\$ 25,014,306,000$ & $\$ 67,202,507,000$ \\
\hline Personal Income & 10.40 & 7.77 & $\$ 6,164,452,000$ & $\$ 7,580,107,000$ & $\$ 7,831,446,000$ & $\$ 21,576,005,000$ \\
\hline Jobs & 10.40 & 7.77 & 90,510 & 127,560 & 185,850 & 403,920 \\
\hline \multicolumn{7}{|l|}{ Low Scenario } \\
\hline Output & 10.31 & 8.44 & $\$ 21,516,485,000$ & $\$ 24,303,706,000$ & $\$ 27,167,792,000$ & $\$ 72,987,983,000$ \\
\hline Personal Income & 10.31 & 8.44 & $\$ 6,695,151,000$ & $\$ 8,232,681,000$ & $\$ 8,505,656,000$ & $\$ 23,433,488,000$ \\
\hline Jobs & 10.31 & 8.44 & 98,300 & 138,540 & 201,850 & 438,690 \\
\hline
\end{tabular}

The 2030 O\&M economic benefits are shown in Table 10 and reflect all of the benefits of PV O\&M spending and electricity bill savings for the cumulative installations through 2030. In the high scenario, the O\&M benefits total over $\$ 31.7$ billion in gross economic output and $\$ 10$ billion in increased personal income. The cumulative employment impact is a gross increase of 237,300 jobs.

In the low scenario, the O\&M impacts remain very significant with a gross increase in economic output of $\$ 21.8$ billion and personal income increasing by $\$ 6.8$ billion annually. The low scenario also results in a gross increase in jobs of 163,150 based on the cumulative installed capacity of $70 \mathrm{GW}$ of PV by 2030.

\footnotetext{
${ }^{16}$ For 2030, the impacts in the low scenario are greater than the high scenario due to growth rates used for this analysis. In this particular year, the incremental amount of PV added in 2030 in the low scenario is greater than the PV capacity added in the high scenario in 2030 ( $8.44 \mathrm{GW}$ and $7.77 \mathrm{GW}$ respectively).
} 
Table 10: Cumulative Gross O\&M Impacts (2030)

\begin{tabular}{|c|c|c|c|c|c|c|}
\hline O\&M Gross Impacts & $\begin{array}{c}\text { Total } \\
\text { Cummulative } \\
\text { Installed } \\
\text { Capacity in } 2030 \\
\end{array}$ & $\begin{array}{c}\text { SAI Induced } \\
\text { Cummulative } \\
\text { Installed Capacity in } \\
2030\end{array}$ & Direct & Indirect & Induced & Total \\
\hline \multicolumn{7}{|l|}{ High Scenario } \\
\hline Output & 100.00 & 80.00 & $\$ 12,162,729,000$ & $\$ 8,390,215,000$ & $\$ 11,190,494,000$ & $\$ 31,743,438,000$ \\
\hline Personal Income & 100.00 & 80.00 & $\$ 3,866,276,000$ & $\$ 2,636,991,000$ & $\$ 3,503,604,000$ & $\$ 10,006,871,000$ \\
\hline Jobs & 100.00 & 80.00 & 101,970 & 52,190 & 83,140 & 237,300 \\
\hline \multicolumn{7}{|l|}{ Low Scenario } \\
\hline Output & 70.00 & 55.00 & $\$ 8,361,876,000$ & $\$ 5,768,273,000$ & $\$ 7,693,465,000$ & $\$ 21,823,614,000$ \\
\hline Personal Income & 70.00 & 55.00 & $\$ 2,658,065,000$ & $\$ 1,812,930,000$ & $\$ 2,408,728,000$ & $\$ 6,879,723,000$ \\
\hline Jobs & 70.00 & 55.00 & 70,110 & 35,880 & 57,160 & 163,150 \\
\hline
\end{tabular}

Note: Table shows annual impacts in 2030 based on cumulative SAI PV installations.

The combined benefits for each activity area for 2030 are summarized in Table 11.

Table 11: Gross Economic Benefit Summary (2030)

\begin{tabular}{|c|c|c|c|}
\hline $\begin{array}{c}\text { Economic Benefit } \\
\text { Category (Gross } \\
\text { Impacts) } \\
\end{array}$ & Construction & O\&M & Total \\
\hline \multicolumn{4}{|l|}{2030 High Scenario } \\
\hline Output & $\$ 67,202,507,000$ & $\$ 31,743,438,000$ & $\$ 98,945,945,000$ \\
\hline Personal Income & $\$ 21,576,005,000$ & $\$ 10,006,871,000$ & $\$ 31,582,876,000$ \\
\hline Jobs & $\$ 403,920$ & $\$ 237,300$ & $\$ 641,220$ \\
\hline \multicolumn{4}{|l|}{2030 Low Scenario } \\
\hline Output & $\$ 72,987,983,000$ & $\$ 21,823,614,000$ & $\$ 94,811,597,000$ \\
\hline Personal Income & $\$ 23,433,488,000$ & $\$ 6,879,723,000$ & $\$ 30,313,211,000$ \\
\hline Jobs & 438,690 & 163,150 & $\$ \quad 601,840$ \\
\hline
\end{tabular}

\section{Net ECONOMIC BENEFITS}

This section describes the net economic benefits that could be expected from the SAI, and takes into account (i.e., subtracts) the changes in economic activity that would have occurred in other sectors if the SAI were not implemented. For each year (2015 and 2030), the results for the construction, O\&M, and R\&D activities are reported. Detailed benefit estimates for all years (2005-2030) for these categories are included in Appendix A.

Table 12 shows the net benefits of the PV system construction (manufacture and installation) for 2015. Again, these results reflect impacts over and above what would have happened in the counterfactual scenario, which assumes natural gas plant construction. The construction results reflect the impacts that occur only during the construction period, which is assumed to be a single year.

For the high scenario, a cumulative total of $10 \mathrm{GW}$ of new PV is installed by 2015. This construction will result in a gross increase in economic output of $\$ 8.5$ billion during the construction period. This will also result in a gross increase in personal income of $\$ 2.9$ billion over the same period.

For the net job impacts, the direct impacts for PV installation are a negative 17,850, meaning that there are more direct jobs initially created by the construction of natural gas plants combined with the spending from households than from the PV manufacture and installations occurring in 2015. However, when the indirect and induced effects of construction spending are taken into account, then the overall net job impact is positive. The overall effect is a net increase of 28,940 jobs over the employment that would occur in the counterfactual scenario. 
The bottom of Table 12 shows the same net results in the construction phase assuming the low scenario of $5 \mathrm{GW}$ of installed PV by 2015. In the low scenario, the SAI results in a net increase of economic output of $\$ 2.5$ billion and a net increase in personal income of $\$ 879$ million over the counterfactual scenario. This also results in a net increase in jobs of 8,770 .

Table 12: Annual Net Construction Impacts (2015)

\begin{tabular}{|c|c|c|c|c|c|c|}
\hline $\begin{array}{c}\text { Construction Net } \\
\text { Impacts }\end{array}$ & $\begin{array}{c}\text { Total Annual } \\
\text { Installed } \\
\text { Capacity In } 2015 \\
\end{array}$ & $\begin{array}{c}\text { SAI Induced } \\
\text { Annual Installed } \\
\text { Capacity In } 2015\end{array}$ & Direct & Indirect & Induced & Total \\
\hline \multicolumn{7}{|c|}{ High Scenario } \\
\hline Output & 2.74 & 2.37 & $\$ 988,946,000$ & $\$ 3,922,413,000$ & $\$ 3,610,641,000$ & $\$ 8,522,000,000$ \\
\hline Personal Income & 2.74 & 2.37 & $\$ 327,745,000$ & $\$ 1,443,688,000$ & $\$ 1,130,363,000$ & $\$ 2,901,796,000$ \\
\hline Jobs & 2.74 & 2.37 & $-17,850$ & 19,960 & 26,830 & 28,940 \\
\hline \multicolumn{7}{|c|}{ Low Scenario } \\
\hline Output & 1.02 & 0.72 & $\$ 299,771,000$ & $\$ 1,188,967,000$ & $\$ 1,094,462,000$ & $\$ 2,583,200,000$ \\
\hline Personal Income & 1.02 & 0.72 & $\$ 99,347,000$ & $\$ 437,613,000$ & $\$ 342,637,000$ & $\$ 879,597,000$ \\
\hline Jobs & 1.02 & 0.72 & $-5,410$ & 6,050 & 8,130 & 8,770 \\
\hline
\end{tabular}

Table 13 shows the net impacts of PV O\&M activities in 2015 for both the high and low SAI scenarios. The O\&M impacts are based on the entire installed PV capacity in 2015 and include maintenance costs as well as money saved on electricity bills due to the PV systems.

For the high scenario, O\&M activities result in a net increase in total economic output of $\$ 518$ million annually based on the $10 \mathrm{GW}$ of installed PV capacity. ${ }^{17}$ Personal income also shows a net increase of over $\$ 361$ million annually and an additional 15,330 jobs are added due to the SAI in 2015.

The low scenario results are also shown in Table 13 for 2015. Since the low scenario is based on half of the installed PV capacity (5 GW rather than $10 \mathrm{GW}$ in 2015), the economic impacts are also reduced by 50 percent relative to the high scenario, with slight differences due to rounding.

Table 13: Cumulative Net O\&M Impacts (2015)

\begin{tabular}{|c|c|c|c|c|c|c|}
\hline O\&M Net Impacts & $\begin{array}{c}\text { Total Cummulative } \\
\text { Installed Capacity } \\
\text { in } 2015\end{array}$ & $\begin{array}{c}\text { SAI Induced } \\
\text { Cummulative } \\
\text { Installed Capacity } \\
\text { in } 2015 \\
\end{array}$ & Direct & Indirect & Induced & Total \\
\hline \multicolumn{7}{|l|}{ High Scenario } \\
\hline Output & 10.00 & 9.00 & $-\$ 141,982,000$ & $\$ 263,195,000$ & $\$ 397,401,000$ & $\$ 518,614,000$ \\
\hline Personal Income & 10.00 & 9.00 & $\$ 141,430,000$ & $\$ 95,235,000$ & $\$ 124,429,000$ & $\$ 361,094,000$ \\
\hline Jobs & 10.00 & 9.00 & 9,840 & 2,540 & 2,950 & 15,330 \\
\hline \multicolumn{7}{|l|}{ Low Scenario } \\
\hline Output & 5.00 & 4.00 & $-\$ 63,103,000$ & $\$ 116,976,000$ & $\$ 176,622,000$ & $\$ 230,495,000$ \\
\hline Personal Income & 5.00 & 4.00 & $\$ 62,857,000$ & $\$ 42,327,000$ & $\$ 55,302,000$ & $\$ 160,486,000$ \\
\hline Jobs & 5.00 & 4.00 & 4,370 & 1,130 & 1,310 & 6,810 \\
\hline
\end{tabular}

Note: Table shows annual impacts in 2030 based on cumulative SAI PV installations.

The economic impacts resulting from the SAI R\&D funding are shown in Table 14 and are based on the annual funding of $\$ 148$ million. Of this budget, 50 percent is assumed to go to private research entities in the U.S. The net impacts are shown relative to the counterfactual scenario that assumes the SAI funding is spent on other Federal programs. Funding is assumed to be constant between the high and low scenarios.

\footnotetext{
${ }^{17}$ The negative direct effect for output is the result of lost utility revenues due to reduced power sales. This is made up in the indirect and induced effects as households use the money saved on their electricity bills to purchase other goods and services.
} 
The spending on solar R\&D through the SAI results in a net increase in economic output of $\$ 118$ million with personal income increasing by $\$ 64$ million. The R\&D funding also results in a net increase of 910 jobs.

Table 14: Annual Net R\&D Impacts (2015)

\begin{tabular}{lccccc}
\hline \multicolumn{1}{c}{ R\&D Net Impacts } & $\begin{array}{c}\text { Annual R\&D } \\
\text { Spending (\$M) }\end{array}$ & Direct & Indirect & Induced & Total \\
\hline \multicolumn{1}{c}{ High Scenario } & $\$ 148,000,000$ & & & & \\
Output & & $\$ 73,634,000$ & $\$ 47,076,000$ & $-\$ 2,704,000$ & $\$ 118,007,000$ \\
Personal Income & & $\$ 48,979,000$ & $\$ 16,121,000$ & $-\$ 846,000$ & $\$ 64,254,000$ \\
Jobs & & 600 & 330 & -20 & 910 \\
\hline \multicolumn{1}{c}{ Low Scenario } & $\$ 148,000,000$ & & & & \\
Output & & $\$ 73,634,000$ & $\$ 47,076,000$ & $-\$ 2,704,000$ & $\$ 118,007,000$ \\
Personal Income & & $\$ 48,979,000$ & $\$ 16,121,000$ & $-\$ 846,000$ & $\$ 64,254,000$ \\
Jobs & & 600 & 330 & -20 & 910 \\
\hline
\end{tabular}

The combined net economic benefits for 2015 across all activities are shown in Table 15. Additional detail on individual years is provided in Appendix A.

Table 15: Net Economic Benefit Summary (2015)

\begin{tabular}{|c|c|c|c|c|}
\hline $\begin{array}{c}\text { Net Economic Benefit } \\
\text { Category (Net } \\
\text { Impacts) } \\
\end{array}$ & Construction & O\&M & R\&D & Total \\
\hline \multicolumn{5}{|l|}{2015 High Scenario } \\
\hline Output & $\$ 8,522,000,000$ & $\$ 518,614,000$ & $\$ 118,007,000$ & $\$ 9,158,621,000$ \\
\hline Personal Income & $\$ 2,901$, & $\$ 361,0$ & $\$ 64,254,000$ & $\$ 3,327,144,000$ \\
\hline Jobs & 28,9 & 15,330 & 910 & 45,180 \\
\hline \multicolumn{5}{|l|}{2015 Low Scenario } \\
\hline Output & $\$ 2,583,200,000$ & $\$ 230,495,000$ & $\$ 118,007,000$ & $\$ 2,931,702,000$ \\
\hline Personal Income & $\$ 879,597,000$ & $\$ 160,486,000$ & $\$ 64,254,000$ & $\$ 1,104,337,000$ \\
\hline Jobs & 8,770 & 6,810 & 910 & 16,490 \\
\hline
\end{tabular}

Figure 1 shows how the net gains in economic output are distributed across sectors for the construction, O\&M, and R\&D phases combined in 2015. The Manufacturing and Construction sectors show large increases due to the manufacture and installation of PV systems. Conversely, the Utility sector shows a net loss in economic activity due to lower electricity sales revenue resulting from the increasing amount of electricity provided by PV. 


\section{Figure 1: 2015 Net Output}

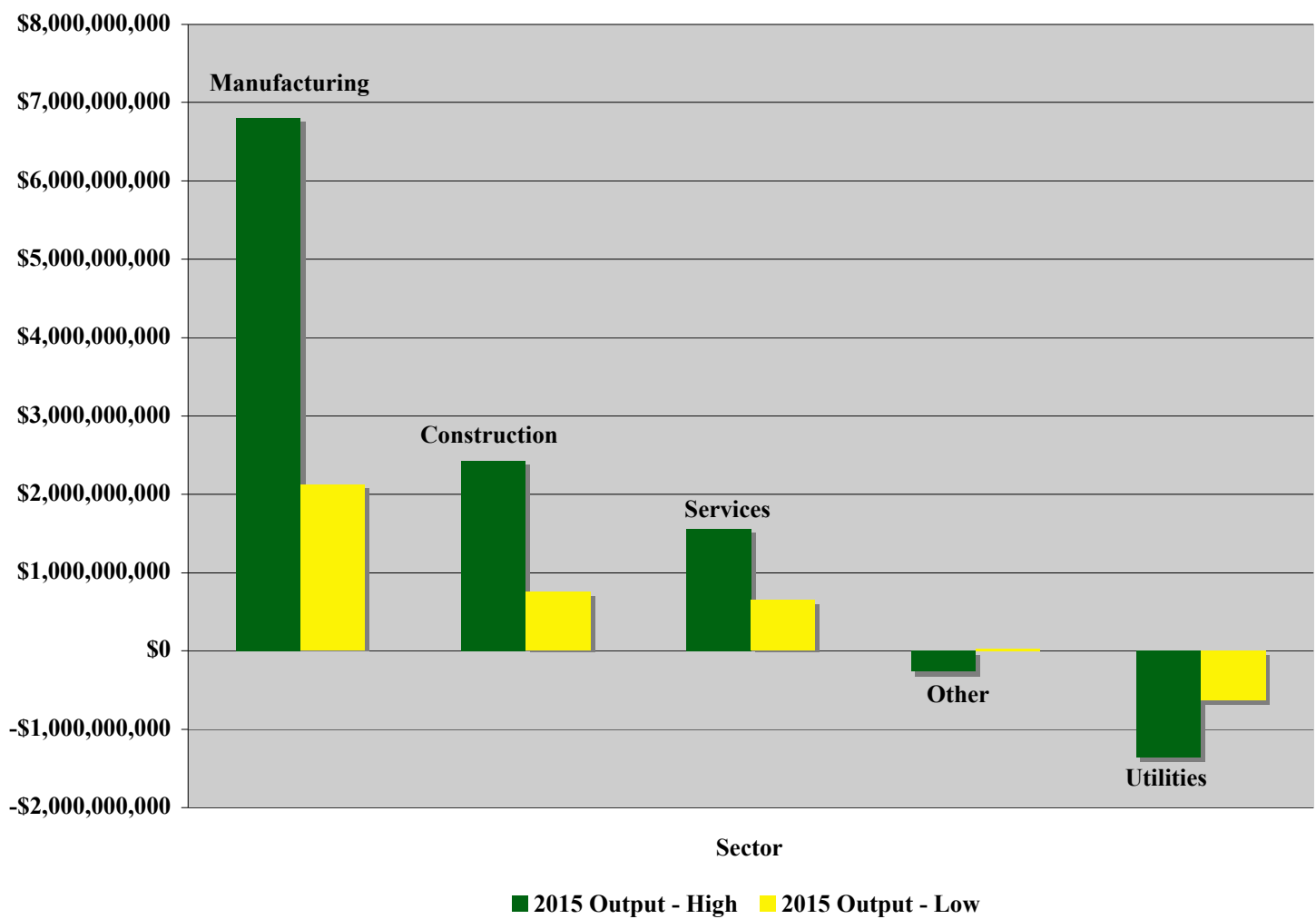

Figure 2 shows how the net change in jobs is distributed across industry sectors. As with economic output, the Manufacturing and Construction sectors show large increases in employment due to the increased production and installation of PV systems. The other sectors show relatively small changes in net employment. Note that while the Utility sector shows a large drop in economic output in Figure 1, a relatively smaller decrease in employment shown in Figure 2. This is due to the fact that the utility sector is not as labor intensive as other industries and that much of the lost economic output shown in Figure 1 is due to fuel purchases (or other non-labor inputs) rather than wages. 


\section{Figure 2: 2015 Net Jobs}

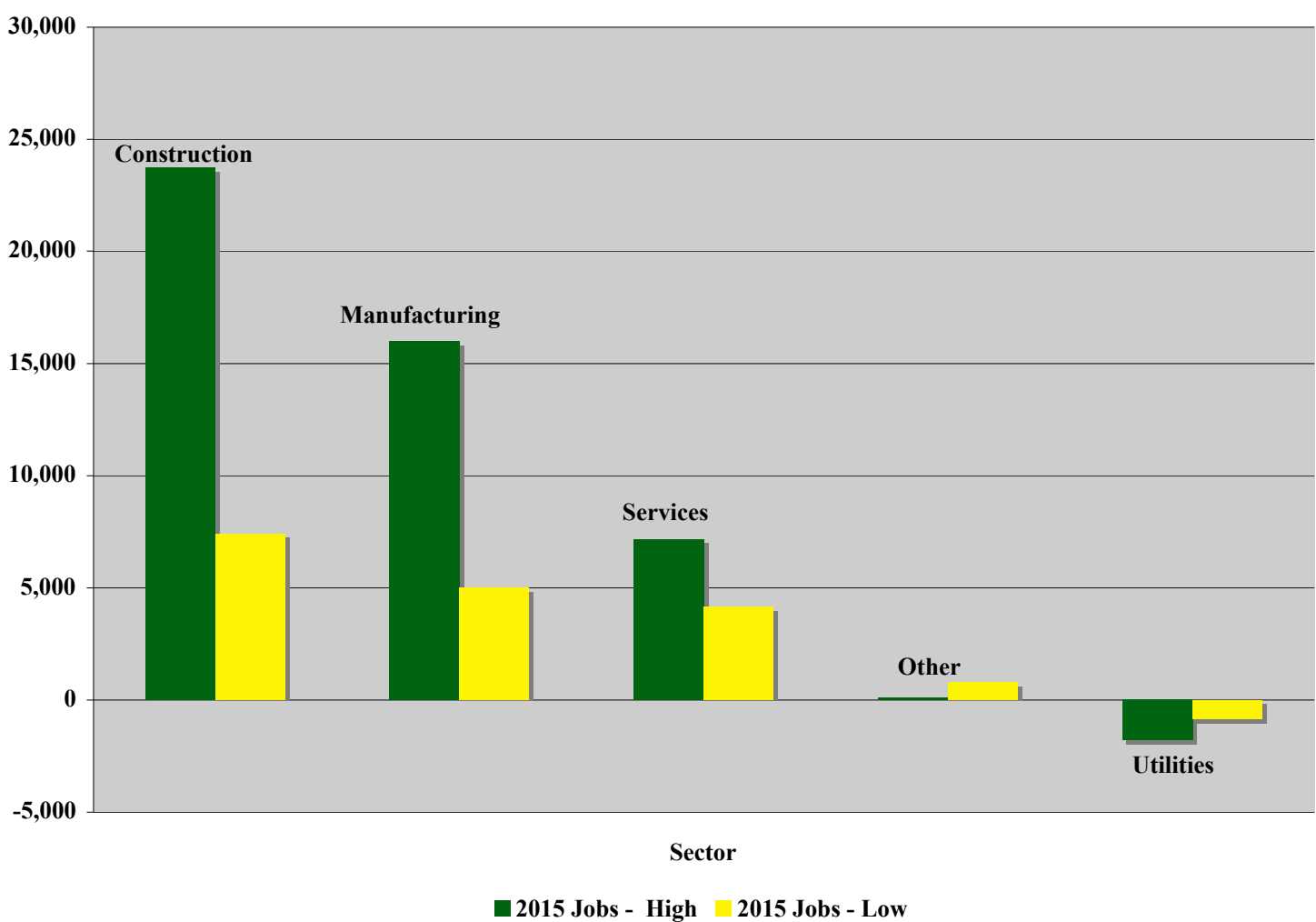

Table 16 shows the construction impacts for 2030 for both the high and low SAI scenarios and assumes that PV costs have fallen to $\$ 2.5 / \mathrm{Wdc}$. In 2030 , total installed capacity is $100 \mathrm{GW}$ for the high scenario. The additional PV construction results in a net increase of $\$ 20.5$ billion in economic output relative to counterfactual scenario and personal income has a net increase of almost $\$ 7$ billion. The PV construction activity also results in a net increase of 69,280 in 2030.

The low scenario construction impacts are greater than the high scenario impacts for 2030, as the low scenario installs more capacity in this particular year compared to the high scenario $(8.44 \mathrm{GW}$ in the low scenario compared with $7.77 \mathrm{GW}$ in the high scenario for 2030). In the low scenario for 2030, net output increases by $\$ 22$ billion, personal income increases by $\$ 7.5$ billion, and jobs show a net increase of 75,230 .

Table 16: Annual Net Construction Impacts (2030)

\begin{tabular}{|c|c|c|c|c|c|c|}
\hline $\begin{array}{c}\text { Construction Net } \\
\text { Impacts }\end{array}$ & $\begin{array}{c}\text { Total Annual } \\
\text { Installed Capacity } \\
\text { In } 2030\end{array}$ & $\begin{array}{c}\text { SAI Induced } \\
\text { Annual Installed } \\
\text { Capacity In } 2030\end{array}$ & Direct & Indirect & Induced & Total \\
\hline \multicolumn{7}{|c|}{ High Scenario } \\
\hline Output & 10.40 & 7.77 & $\$ 2,352,777,000$ & $\$ 9,499,047,000$ & $\$ 8,651,896,000$ & $\$ 20,503,720,000$ \\
\hline Personal Income & 10.40 & 7.77 & $\$ 718,510,000$ & $\$ 3,502,286,000$ & $\$ 2,708,602,000$ & $\$ 6,929,398,000$ \\
\hline Jobs & 10.40 & 7.77 & $-43,300$ & 48,300 & 64,280 & 69,280 \\
\hline \multicolumn{7}{|c|}{ Low Scenario } \\
\hline Output & 10.31 & 8.44 & $\$ 2,555,328,000$ & $\$ 10,316,822,000$ & $\$ 9,396,739,000$ & $\$ 22,268,889,000$ \\
\hline Personal Income & 10.31 & 8.44 & $\$ 780,366,000$ & $\$ 3,803,798,000$ & $\$ 2,941,786,000$ & $\$ 7,525,950,000$ \\
\hline Jobs & 10.31 & 8.44 & $-47,030$ & 52,450 & 69,810 & 75,230 \\
\hline
\end{tabular}


The 2030 O\&M economic benefits are shown in Table 17 and reflect all of the benefits of PV O\&M spending and electricity bill savings for the cumulative installations through 2030 . In the high scenario, the O\&M benefits total over $\$ 3.7$ billion in net economic output and $\$ 2.8$ billion in increased personal income. The cumulative employment impact is a net increase of 129,120 jobs over the counterfactual scenario.

In the low scenario, the O\&M impacts remain very significant with a net increase in economic output of $\$ 2.6$ billion and personal income increasing by $\$ 1.9$ billion annually. The low scenario also results in a net increase in jobs of 88,770 based on the cumulative installed capacity of $70 \mathrm{GW}$ of PV by 2030.

Table 17: Cumulative Net O\&M Impacts (2030)

\begin{tabular}{|c|c|c|c|c|c|c|}
\hline O\&M Net Impacts & $\begin{array}{c}\text { Total Cummulative } \\
\text { Installed Capacity } \\
\text { in } 2030\end{array}$ & $\begin{array}{c}\text { SAI Induced } \\
\text { Cummulative } \\
\text { Installed Capacity } \\
\text { in } 2030\end{array}$ & Direct & Indirect & Induced & Total \\
\hline \multicolumn{7}{|c|}{ High Scenario } \\
\hline Output & 100.00 & 80.00 & $-\$ 1,542,062,000$ & $\$ 2,184,665,000$ & $\$ 3,155,011,000$ & $\$ 3,797,614,000$ \\
\hline Personal Income & 100.00 & 80.00 & $\$ 1,091,503,000$ & $\$ 798,895,000$ & $\$ 987,867,000$ & $\$ 2,878,265,000$ \\
\hline Jobs & 100.00 & 80.00 & 84,060 & 21,620 & 23,440 & 129,120 \\
\hline \multicolumn{7}{|c|}{ Low Scenario } \\
\hline Output & 80.00 & 55.00 & $-\$ 1,060,168,000$ & $\$ 1,501,957,000$ & $\$ 2,169,070,000$ & $\$ 2,610,859,000$ \\
\hline Personal Income & 80.00 & 55.00 & $\$ 750,408,000$ & $\$ 549,240,000$ & $\$ 679,158,000$ & $\$ 1,978,806,000$ \\
\hline Jobs & 80.00 & 55.00 & 57,790 & 14,860 & 16,120 & 88,770 \\
\hline
\end{tabular}

Note: Table shows annual impacts in 2030 based on cumulative SAI PV installations.

The combined net benefits for each activity area are summarized in Table 18 for 2030.

Table 18: Net Economic Benefit Summary (2030)

\begin{tabular}{|c|c|c|c|}
\hline $\begin{array}{c}\text { Net Economic Benefit } \\
\text { Category (Net } \\
\text { Impacts) }\end{array}$ & Construction & O\&M & Total \\
\hline \multicolumn{4}{|l|}{2030 High Scenario } \\
\hline Output & $\$ 20,503,720,000$ & $\$ 3,797,614,000$ & $\$ 24,301,334,000$ \\
\hline Personal Income & $\$ 6,929,398,000$ & $\$ 2,878,265,000$ & $\$ 9,807,663,000$ \\
\hline Jobs & 69,280 & 129,120 & $\$ 198,400$ \\
\hline \multicolumn{4}{|l|}{2030 Low Scenario } \\
\hline Output & $\$ 22,268,889,000$ & $\$ 2,610,859,000$ & $\$ 24,879,748,000$ \\
\hline Personal Income & $\$ 7,525,950,000$ & $\$ 1,978,806,000$ & $\$ 9,504,756,000$ \\
\hline Jobs & 75,230 & 88,770 & $\$ 164,000$ \\
\hline
\end{tabular}

Figure 3 shows how the combined economic output estimates from the construction, O\&M, and R\&D activities for 2030 are distributed across economic sectors. Compared with the chart for 2015, the magnitude of the changes in output are much greater due to the much higher levels of PV installed in 2030 relative to 2015. As in 2015, the Manufacturing sector shows the largest net gains in economic output due to the increase in the manufacture and installation of PV systems. The Services and Construction sectors also see significant net gains in economic output due to the SAI relative to the counterfactual scenario. The Utility sector sees a significant decrease in economic output from the lower electricity sales that result from the increase in PV capacity by 2030. 


\section{Figure 3: 2030 Net Output}

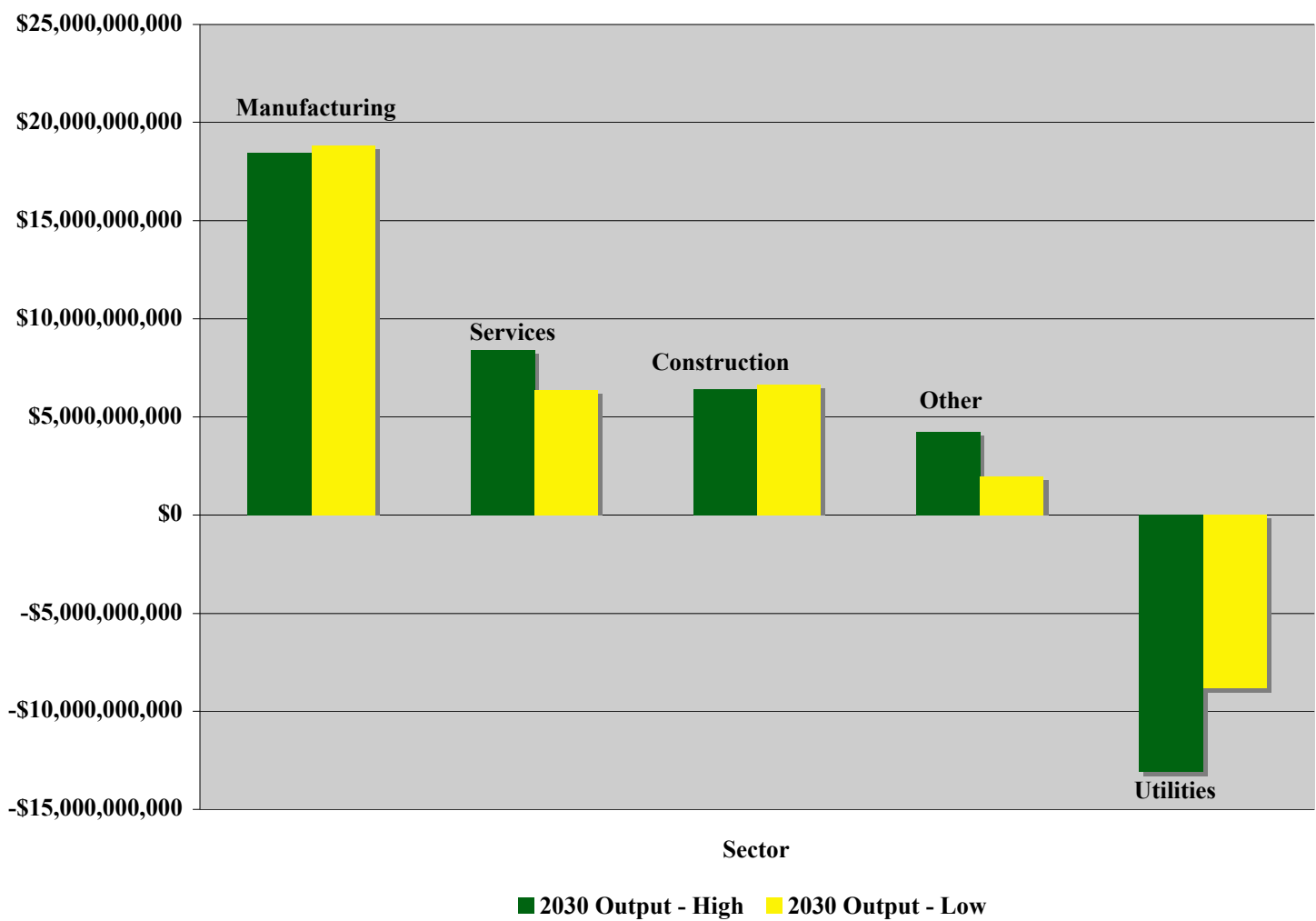

Figure 4 shows how the net change in jobs is distributed across industry sectors in 2030. The Services sector shows the largest gains in employment due to the SAI, followed by Construction and Manufacturing. Note that Services shows a large increase in employment relative to the change in output shown in Figure 3. The large increase in employment is due to the labor-intensive jobs that are included in the Service sector. 


\section{Figure 4: 2030 Net Jobs}

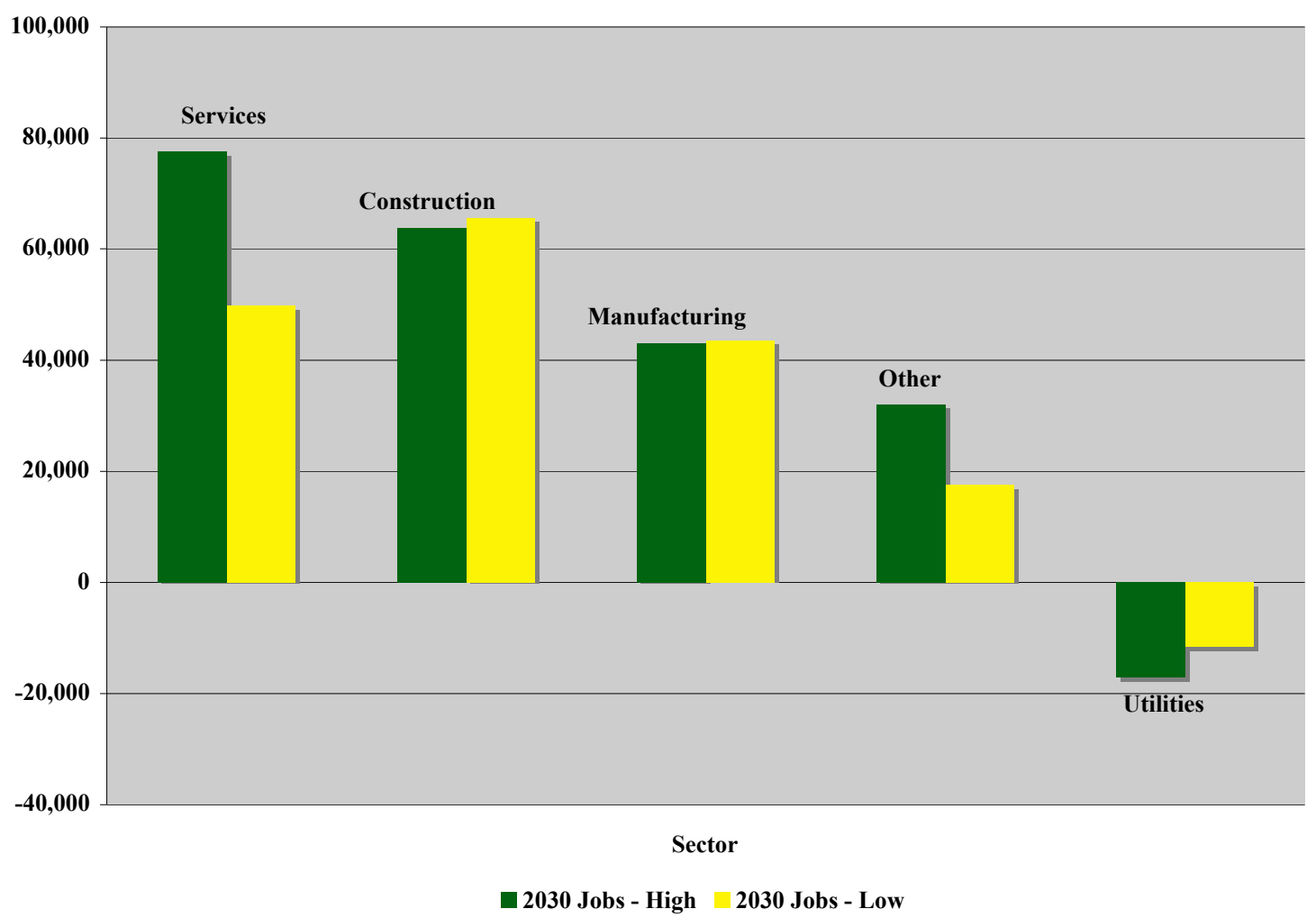

All of the preceding economic benefit estimates assume a constant electricity price that has been adjusted for inflation but does not account for any additional price increases during the analysis period. If the electricity price does increase over time, then the economic benefits of the SAI will increase as customers with PV systems receive a greater benefit through reduced electricity bills. In the benefit framework discussed here, an increase in price will effect the benefit estimates only through the O\&M benefits, as the Construction and R\&D phases are unaffected by changes in the electricity prices.

The economic benefits are estimated assuming an electricity price of $\$ 0.0966 / \mathrm{kWh}$. If this is increased by 1 cent to $\$ 0.1066 / \mathrm{kWh}$, then the O\&M jobs impacts are expected to increase by 8 to 9 percent. Similarly, a 1-cent increase in price will also increase personal income by 6 to 7 percent while the impact on economic output is expected to increase by 3 percent. This relationship is relatively consistent across years.

Selected price sensitivity examples are shown in Table 19 for the low scenario and the relative effects, in percentage terms, are the same in the high scenario (not shown). While only a 1-cent change is shown, the relationship is linear and each 1-cent change in the price of electricity will increase the net economic output by 3 percent, personal income by 6 to 7 percent, and jobs by 8 to 9 percent. 
Table 19: Effect of a 1-Cent Electricity Price Change on O\&M Benefits

\begin{tabular}{|c|c|c|c|}
\hline $\begin{array}{l}\text { O\&M Economic } \\
\text { Benefit Category }\end{array}$ & $\begin{array}{c}\text { Electricity Price } \\
\$ 0.0966 / \mathrm{kWh}\end{array}$ & $\begin{array}{c}\text { Electricity } \\
\text { Price } \\
\$ 0.1066 / \mathbf{k W h}\end{array}$ & $\begin{array}{l}\text { Percent } \\
\text { Change }\end{array}$ \\
\hline \multicolumn{4}{|l|}{2015 Low Scenario } \\
\hline Output & $\$ 230,495,000$ & $\$ 237,013,000$ & $3 \%$ \\
\hline Personal Income & $\$ 160,486,000$ & $\$ 170,023,000$ & $6 \%$ \\
\hline Jobs & 6,810 & 7,370 & $8 \%$ \\
\hline \multicolumn{4}{|l|}{2030 Low Scenario } \\
\hline Output & $\$ 2,610,859,000$ & $\$ 2,700,478,000$ & $3 \%$ \\
\hline Personal Income & $\$ 1,978,806,000$ & $\$ 2,109,935,000$ & $7 \%$ \\
\hline Jobs & 88,770 & 96,360 & $9 \%$ \\
\hline
\end{tabular}




\section{ENVIRONMENTAL BENEFITS}

This section of the report describes the major environmental and health benefits that could be expected as a result of attaining SAI solar generation goals, and thereby reducing fossil fuel-fired electricity generation. In particular, we focus on the impacts of reducing $\mathrm{CO}_{2}, \mathrm{NO}_{\mathrm{X}}$ and $\mathrm{SO}_{2}$ emissions. Our analysis of these benefits utilizes the energy calculations described in the Energy Benefits section of this report that show the amount of displaced electricity generation that will result should the SAI PV installation goals be achieved.

The U.S. Environmental Protection Agency (EPA) reports that electricity generation is currently the largest industrial source of air emissions in the United States. Fossil fuel-fired power plants are responsible for 40 percent of man-made carbon dioxide $\left(\mathrm{CO}_{2}\right)$ emissions, 23 percent of the nation's nitrogen oxide $\left(\mathrm{NO}_{\mathrm{X}}\right)$ emissions, and 67 percent of sulfur dioxide $\left(\mathrm{SO}_{2}\right)$ emissions. ${ }^{18}$ These emissions contribute to the formation of smog and haze, and are associated with a wide range of health problems. In addition, greenhouse gases (e.g., carbon dioxide) emitted by fossil fuel-fired power plants increase the risk of climate change. In comparison, the emissions from solar electricity generation are negligible as no fossil fuels are combusted to create electricity.

\section{EMISSIONS REDUCED BY SAI}

The emissions offset or reduced by new PV capacity are calculated by taking the amount of fossil fuel generation offset by PV and multiplying by the average emissions rates for those fuels. A wide range of fossil fuel emission rates for $\mathrm{CO}_{2}, \mathrm{NO}_{\mathrm{X}}$ and $\mathrm{SO}_{2}$ was found in the literature. Most of these studies, however, were regionally based and were affected by local emissions regulations and trading schemes, unique plant types and emission cleaning technologies, and/or utilized highly refined regional economic dispatch models. For this analysis, we elected to use broader and more generic emission rates based on national generating plant data rather than use factors that were derived from a region-specific study.

Table 20 shows two sets of emission rates that could be applied for this analysis. One set of rates was calculated by EPA using national generating plant data from the eGRID 2000 database. ${ }^{19}$ A second set of rates was calculated by ECONorthwest using the most current eGRID data available. These rates are based on plant net generation before entering the grid, which subtracts plant auxiliary power consumption (e.g., for scrubbers, cooling fans, turbine auxiliaries) from gross generation. ${ }^{20}$

The subsequent results for emissions avoided and associated health impacts are based on the more current eGRID 2006 emission rate estimates. These emission rates are generally lower than the 2000 rates, and likely reflect more efficient generating plants and growing adoption of emissions cleaning technologies to meet local and federal air quality standards. ${ }^{21}$

\footnotetext{
${ }^{18}$ www.epa.gov/cleanenergy/emissions.htm

${ }^{19}$ See www.epa.gov/cleanenergy/natgas.htm and www.epa.gov/cleanenergy/coal.htm.

${ }^{20}$ Plants with negative net generation were not considered in the analysis. Plant gross generation and on-site power consumption are not provided in the eGRID 2006 data. The emission rates are based on total plant heat input, total emissions, and net generation.

${ }^{21}$ The ECONorthwest emission rates are based on calculated average heat conversion rates of approximately $9,900 \mathrm{Btu} / \mathrm{kWh}$ for natural gas plants and 10,500 Btu/kWh for coal plants. These heat rates are based on plant heat input and net generation.
} 
Table 20: Average Emission Rates (Ibs/MWh)

\begin{tabular}{l|ccc|ccc}
\hline \multicolumn{1}{c|}{ Source } & \multicolumn{3}{c|}{ Natural Gas } & \multicolumn{3}{c}{ Coal } \\
& $\mathbf{C O}_{2}$ & $\mathbf{N O}_{\mathbf{x}}$ & $\mathbf{S O}_{2}$ & $\mathbf{C O}_{2}$ & $\mathbf{N O}_{\mathbf{x}}$ & $\mathbf{S O}_{2}$ \\
\hline EPA, eGRID 2000 & 1,135 & 1.70 & 0.10 & 2,249 & 6.00 & 13.00 \\
ECONorthwest, eGRID 2006* & 1,169 & 0.69 & 0.02 & 2,164 & 3.50 & 10.30 \\
\hline
\end{tabular}

*2004 plant level data

Table 21 shows the emissions that would by avoided, by fuel type, for the 2015 and 2030 PV capacity scenarios. The SAI is projected to reduce annual $\mathrm{CO}_{2}$ emissions by 69 to 100 million tons in 2030 . Annual $\mathrm{NO}_{\mathrm{X}}$ emissions would be reduced by 68,000 to 99,000 tons, and $\mathrm{SO}_{2}$ emissions would be reduced by 126,000 to 184,000 tons. These results assume that PV generation would replace fossil fuel generation on a one-to-one basis, and that 75 percent of the fuel displaced would be natural gas and 25 percent would be coal. PV systems only generate power during daylight hours and in many regions of the country they would reduce emissions from natural gas peaking units, as these are used in many regions to meet peak (usually daytime) electricity demand ${ }^{22}$. Some areas of the country, however, remain heavily coaldependent, and meet increases in peak demand by increasing output at "spinning reserve" and "standby" plants that operate at less than full capacity.

Table 21: Emissions Avoided by Displaced Fuel (Annual Tons)

\begin{tabular}{|c|c|c|c|c|c|c|c|c|c|c|}
\hline & Installed PV & \multicolumn{3}{|c|}{ Natural Gas } & \multicolumn{3}{c|}{ Coal } & \multicolumn{3}{c|}{ Total } \\
\hline Scenario & Capacity (GW) & $\mathbf{C O}_{2}$ & $\mathbf{N O}_{\mathbf{x}}$ & $\mathbf{S O}_{2}$ & $\mathbf{C O}_{2}$ & $\mathbf{N O}_{\mathbf{x}}$ & $\mathbf{S O}_{2}$ & $\mathbf{C O}_{2}$ & $\mathbf{N O}_{\mathbf{x}}$ & $\mathbf{S O}_{2}$ \\
\hline $\mathbf{2 0 1 5}$ Low & 5 & $3,122,822$ & 1,843 & 40 & $1,926,942$ & 3,117 & 9,172 & $5,049,765$ & 4,960 & 9,212 \\
\hline $\mathbf{2 0 1 5}$ High & 10 & $7,026,350$ & 4,147 & 90 & $4,335,621$ & 7,012 & 20,636 & $11,361,970$ & 11,160 & 20,726 \\
\hline $\mathbf{2 0 3 0}$ Low & 70 & $42,938,805$ & 25,345 & 551 & $26,495,459$ & 42,853 & 126,111 & $69,434,264$ & 68,198 & 126,662 \\
\hline $\mathbf{2 0 3 0}$ High & 100 & $62,456,444$ & 36,865 & 801 & $38,538,849$ & 62,332 & 183,434 & $100,995,293$ & 99,197 & 184,235 \\
\hline
\end{tabular}

\section{HeALTh Benefits}

Table 22 shows the estimated health benefits that would result from reducing emissions from fossil-fired power generation. Health impacts were related to total emissions of $\mathrm{NO}_{\mathrm{X}}$ and $\mathrm{SO}_{2}$, which react with other chemicals to form fine particulate matter $\left(\mathrm{PM}_{2.5}\right)$ in the air. To estimate health benefits from reduced emissions, we used benefit estimates developed by $\mathrm{EPA}^{23}$ and the Clean Air Task Force ${ }^{24}$ in their analyses of the Clear Skies Act and alternative regulatory scenarios. In those studies, very detailed air quality models were utilized to estimate $\mathrm{PM}$ formation based on $\mathrm{NO}_{\mathrm{X}}$ and $\mathrm{SO}_{2}$ emissions. Since we did not have access to these air quality models for this analysis, we analyzed the assumed $\mathrm{NO}_{\mathrm{X}}$ and $\mathrm{SO}_{2}$ reductions in reported in these studies and found that they were highly correlated with the estimated health impacts. For this study, we applied the emissions/health relationships we discerned in the EPA studies to extrapolate health benefits from the $\mathrm{NO}_{\mathrm{X}}$ and $\mathrm{SO}_{2}$ emission reductions due to the $\mathrm{SAI}$ (rather than from PM formation, which is the method EPA and the Clean Air Task Force used).

\footnotetext{
${ }^{22}$ Connors, Stephen with Edward Kern, Michael Adams, Katherine Martin and Baafour Asiamah-Adjei. National Assessment of Emissions Reduction of Photovoltaic (PV) Power Systems. Prepared for US EPA Air Pollution Prevention and Control Division. 2005 .

${ }^{23}$ United States Environmental Protection Agency. Technical Addendum: Methodologies for the Benefit Analysis of the Clear Skies Act of 2003. September 2003.

${ }^{24}$ Abt Associates Inc. Power Plant Emissions: Particulate Matter-Related Health Damages and the Benefits of Alternative Emission Reduction Scenarios. Prepared for Clean Air Task Force. Boston MA. June 2004.
} 
As shown in the table, the emissions reductions resulting from the SAI will have a positive impact on a range of respiratory and cardio health issues. In particular, the reduced emissions are expected to have a significant effect on the amount of workdays lost or restricted as shown at the bottom of the table. Note that lost and restricted workdays are not included in the economic benefits discussed in the previous section and therefore reflect an additional economic benefit resulting from the SAI.

The EPA studies note that there do not appear to be any PM thresholds beyond which health problems increase significantly. Instead, there is limited evidence that for PM, health effects may actually be greater at lower levels of exposure, and lower at higher levels of ambient PM. While the emission reductions in our analysis are significantly below those analyzed in the Clear Skies studies, we did not adjust the health impact estimates up or down to account for potential ambient PM threshold issues, which is still a focus of ongoing air quality research.

Table 22: Health Impacts Due to Reduced Emissions

\begin{tabular}{|l|c|c|c|c|}
\hline Scenario & 2015 Low & 2015 High & 2030 Low & 2030 High \\
\hline Installed PV Capacity (GW) & $\mathbf{5}$ & $\mathbf{1 0}$ & $\mathbf{7 0}$ & $\mathbf{1 0 0}$ \\
\hline Cases Reduced & & & & \\
\hline Mortality & 22 & 49 & 300 & 437 \\
\hline Chronic Bronchitis & 15 & 34 & 206 & 300 \\
\hline Heart Attacks & 36 & 81 & 493 & 717 \\
\hline Hospital Admissions - Respiratory & & & & \\
\hline Chronic Lung, less Asthma (20-64) & 1 & 2 & 14 & 21 \\
\hline Asthma (0-64) & 2 & 4 & 25 & 36 \\
\hline Pneumonia (65+) & 7 & 17 & 102 & 148 \\
\hline Chronic Lung (65+) & 1 & 2 & 13 & 18 \\
\hline Total & 11 & 25 & 153 & 223 \\
\hline Hospital Admissions - Cardiovascular & & & & \\
\hline All Cardiovascular (20-64) & 4 & 8 & 51 & 74 \\
\hline All Cardiovascular (65+) & 5 & 12 & 73 & 106 \\
\hline Total & 9 & 20 & 124 & 180 \\
\hline Emergency Room Visits for Asthma & 24 & 53 & 324 & 471 \\
\hline Acute Bronchitis & 35 & 78 & 479 & 697 \\
\hline Lower Respiratory Symptoms & 397 & 894 & 5,462 & 7,945 \\
\hline Upper Respiratory Symptoms & 319 & 718 & 4,387 & 6,381 \\
\hline Work Loss Days & 2,538 & 5,710 & 34,894 & 50,755 \\
\hline Minor Restricted Activity Days & 17,439 & 39,239 & 239,791 & 348,787 \\
\hline
\end{tabular}




\section{Additional Energy Benefits}

In addition to the benefits described in the prior sections, the SAI has the potential to create additional, ancillary energy benefits that are less direct than the ones described earlier. For this analysis, we reviewed the current literature to identify the additional benefit areas that are relevant to the SAI. The potential benefits are discussed below along with a discussion of the potential magnitude of these benefits should the SAI goals be achieved.

\section{Price Impacts}

There have been several recent studies that show a link between increased renewable energy deployment and lower natural gas prices. This is an important benefit to consider as small price decreases can result in very large benefits given the large number of electricity customers that will be affected.

Wiser et al. (2005) reviewed several studies to assess how renewable energy development (to meet proposed renewable portfolio standards) could affect natural gas prices in the U.S. These studies, conducted by the EIA, the Union for Concerned Scientists (UCS) and the Tellus Institute indicate that increased use of renewable energy or higher levels of energy efficiency would put downward pressure on natural gas prices. From these studies, Wiser concludes that each 1 percent reduction in natural gas demand due to an increased supply of renewable energy or enhanced energy efficiency would lead to long-term average wellhead price reductions of between 0.8 and 2 percent. Wiser also concludes that in the short-term, the average consumer would not see reductions in their electricity bills; they would probably remain the same. While natural gas prices would fall somewhat, the cost of meeting national renewable portfolio standards of 10 to 20 percent renewable energy would be quite high, and will remain high in the short-term. That said, Wiser et al. (2004b) notes that increased renewable energy use would help to hedge natural gas price volatility due to supply shocks.

The Union of Concerned Scientists (UCS, 2003) also reports that increased use of renewable energy would cause a reduced natural gas demand and prices. For each 1 percent of renewable energy added to total electricity capacity in the U.S., the price of natural gas would fall between .45 and .60 percent, depending on how much renewable energy is installed. The UCS indicates that there would be a decreasing rate of gas price reduction as total generating capacity increases.

If the mid-point of Wiser et al's elasticity range is used (1.4), the expected effect of a 1 percent increase in the quantity of renewable energy would be a 1.4 percent decrease in natural gas prices. Recall that if the SAI goals are met, PV will displace 0.2 to 0.4 percent of forecasted natural gas demand in 2015 and 2 to 4 percent of natural gas demand in 2030. With the 1.4 inverse elasticity, the change in consumption would result in a similar decrease in natural gas prices of 0.3 to 0.6 percent in 2015 and 3 to 6 percent in 2030 . This simple example obviously does not account for a host of other factors that will impact natural gas prices during the same period. Nevertheless, given the increasing U.S. demand for natural gas and the large number of natural gas customers, any decrease in natural gas prices due to the SAI will have wide reaching impacts.

\section{T\&D Benefits}

Two primary costs associated with the transmission and distribution of electricity are the capital and operating costs of the infrastructure (e.g., lines, substations) and electricity that is lost as it travels through the wires from generating plants to end users (i.e., efficiency losses). Transmission and distribution costs can vary greatly depending on locational factors specific to a particular region (e.g., the dispersion of electricity users, geographic constraints that affect capacity expansions, plant locations) and time of day electricity use (i.e. demand patterns). An effective means for reducing these costs is to increase the use of 
distributed energy resources, which do not rely on the T\&D infrastructure. As this suggests, the SAI PV installations may produce significant benefits in terms of reduced T\&D losses and stress on the existing T\&D infrastructure.

In its planning study for the California Public Utilities Commission (CPUC), the Energy and Environmental Economics Group (E3, 2004) note that average electric transmission costs range widely from $\$ 1.16 / \mathrm{kW}$-year to $\$ 18.81 / \mathrm{kW}$-year in California, depending on the utility and geographic zone that is analyzed. These costs are for the construction of transmission and distribution infrastructure. Thus, on average, every $\mathrm{kW}$ of load that could be reduced by greater transmission efficiency is worth approximately $\$ 10.00$ in savings per year in California.

The U.S. Climate Change Technology Program (2003) estimates that in the next decade, the demand for electricity transmission capacity will greatly exceed the construction of infrastructure. While line-miles are only projected to increase by 6 percent, demand is expected to increase by more than 20 percent. The amount of electricity that must be pushed through existing lines will increase, causing increased energy losses and transmission congestion. As a result, grid reliability will likely decrease, resulting in more transmission failures and blackouts.

In 1995, the U.S. transmission and distribution system had energy losses of 7.2 percent (Climate Change Technology Program), and other studies find similar rates ranging from 5 to 10 percent. Connors et al. (2005) estimated average line losses to be between 5 and 12 percent of net generation by comparing EIA data on net generation to retail electricity sales (the difference between the two is presumed to equal line losses). In another California study, Itron (2005) estimated that over the entire year, line loss costs range from $\$ 0.00$ to $\$ 0.12$ per $\mathrm{kWh}$.

Based on these studies, we use 7 percent to account for T\&D losses in our economic impact analysis as this is approximately the midpoint of the range of estimates found in the literature.

\section{Blackout Prevention / Power Reliability}

Consumers place a high value on the reliability of their electricity supply, and many authors have noted the potential reliability benefits of developing more distributed electrical generating systems (e.g., Young 2004, Itron 2005, Hadley et al. 2003). In particular, studies have focused on the causes and economic impacts of power blackouts, and the potential role that PV generation could play in mitigating blackouts.

Blackouts are typically caused by one or more of the following factors: unusually high demand, often related to extreme weather; equipment failure; high power transfer activity (which can lead to line overloads); and human/operator error. Gellings and Yeager (2004) estimated the annual cost of power blackouts in the US to be about $\$ 100$ billion. Due to the unpredictability of blackout occurrences (i.e., frequency, location, duration, precise causes), however, this study does not try to quantify total "blackout prevention benefits" that could be attributable to PV generation under the SAI. That said, information is presented here that shows that the economic costs of blackouts are high, and that PV installations that lead to increased system stability could have significant economic benefits.

Several studies have also analyzed the August 2003 blackout that lost 62,000 MW of power and affected over 50 million people in the Northeast region of the country. ICF (2003) used preliminary information about the blackout and extrapolated findings from previous analyses to estimate the economic costs of this outage to be between $\$ 7$ and $\$ 10$ billion. Perez et al. (2004) subsequently analyzed the precise causes of the blackout, and estimated that the availability of less than $500 \mathrm{MW}$ of PV resources would have been sufficient to prevent the cascading blackout. More specifically, Perez et al. found that regionally dispersed PV could have reduced the need for the large national power transfers that were occurring, and alleviated 
conditions contributing to the eventual blackout. They also note that in the case of the 2003 Northeast blackout, PV effective capacity was particularly high in the region (due to little cloud cover) and was directly related to high air conditioning demand (the fundamental cause of the blackout). The authors conclude that in some situations, PV can act as a natural offset or hedge against blackout causes, and that PV (and other distributed generation sources) can work in conjunction with and in parallel to gridsupplied power to improve system reliability. 


\section{SUMmARY AND CONCLUSIONS}

Based on our analysis, achieving the SAI PV installation goals will result in a wide range of significant benefits:

- The SAI is expected to produce significant economic benefits over and above what would be achieved in the counterfactual scenario where the SAI generation is instead supplied by conventional sources. If the 2015 SAI goals are reached, economic output will have a net increase of $\$ 2.9$ to 9.1 billion and 16,000 to 45,000 new jobs will be created. By 2030, the SAI results in an increase of $\$ 25$ billion in economic output and 165,000 to 199,000 new jobs.

- The economic benefits assume that the price of electricity remains constant (except for inflation) throughout the analysis period. Most predictions indicate the price of electricity will increase, however, particularly for electricity generated by natural gas, which is the most likely source to be offset by the SAI. When price increases are considered in the analysis, a 1-cent increase in electricity prices will increase the net economic output from PV O\&M by 3 percent. Similarly, every 1-cent increase in electricity prices will also increase the PV O\&M personal income benefit by 6 to 7 percent and the net number of new jobs by 8 to 9 percent annually.

- The SAI PV installations will also have a significant effect in reducing emissions. If the 2015 SAI goals are met, emissions of $\mathrm{CO}_{2}$ will decrease by 5 to 11 million tons annually, $\mathrm{NO}_{\mathrm{X}}$ emissions will decrease by 5,000 to 11,200 tons annually, and $\mathrm{SO}_{2}$ emissions will fall by 9,200 to 20,700 tons annually. By 2030, the SAI will result in decreased $\mathrm{CO}_{2}$ emissions of 69 to 100 million tons annually, decreased $\mathrm{NO}_{\mathrm{X}}$ emissions by 68,000 to 99,000 tons annually, and decreased $\mathrm{SO}_{2}$ emissions by 126,000 to 184,000 tons annually. These emissions reductions will continue each year the PV equipment remains installed.

- The reduced emissions will have a corresponding influence on health benefits in addition to reductions in global warming and acid rain. In 2015, the reduced emissions should result in a decrease in mortality of 22 to 49 , with this number increasing to 300 to 437 deaths avoided annually by 2030 . The improved health benefits due to the SAI is also expected to reduce the lost number of work days, with lost work days falling by 2,500 to 5,700 annually in 2015 and decreasing 35,000 to 51,000 annually in 2030 .

- Increasing the deployment of PV through the SAI will reduce demands on natural gas, which in turn will reduce the price of natural gas. If the inverse price elasticity of 1.4 is used, then the SAI PV installations will have the effect of reducing natural gas prices by 0.3 to 0.6 percent in 2015 and 3 to 6 percent in 2030. This has potentially far reaching effects, as even a small reduction in the price of natural gas will be felt by all customers that rely on natural gas for electricity generation.

- Finally, several studies have researched the potential benefits of using PV and other distributed energy resources to reduce the risk of blackouts. Large regional blackouts are expensive and disruptive to the economy and have been estimated to cost the U.S. $\$ 100$ billion annually. Research suggests that $500 \mathrm{MW}$ of PV may have been enough to avoid this blackout. The ability of PV to prevent specific blackouts will depend on very specific information on where the PV installations are installed and their ability to relieve pressure on the high stress points on the grid. While this level of detail is outside the scope of this study, it appears that there will be some potential benefit for blackout prevention should the SAI PV goals be achieved. 


\section{REFERENCES}

Abt Associates, Inc. "Power Plant Emissions: Particulate Matter-Related Health Damages and the Benefits of Alternative Emission Reduction Scenarios." Prepared for Clean Air Task Force. Boston MA. June 2004.

American Council for an Energy-Efficient Economy (ACEEE). "Natural Gas Price Effects of Energy Efficiency and Renewable Energy Practices and Policies.” Report Number E032. Washington, D.C., 2003.

Awerbuch, Shimon. "Determining the Real Cost: Why Renewable Power is More Cost-Competitive than Previously Believed.” Renewable Energy World, James and James (Science Publishers) Ltd., April 2003.

Bolinger, Mark and Ryan Wiser and W. Golove. "Accounting for Fuel Price Risk: Using Forward Natural Gas Prices Instead of Gas Price Forecasts to Compare Renewable to Natural Gas-Fired Generation." Lawrence Berkeley Laboratory, 2003.

Connors, Stephen and Edward Kern, Michael Adams, Katherine Martin and Baafour Asiamah-Adjei. "National Assessment of Emissions Reduction of Photovoltaic (PV) Power Systems." Prepared for United States Environmental Protection Agency, Air Pollution Prevention and Control Division. 2005.

Denholm, P. and R. Margolis. "Very Large-Scale Deployment of Grid-Connected Solar Photovoltaics in the United States: Challenges and Opportunities." Prepared for the American Solar Energy Society Solar 2006 Conference, Denver, CO, July 2006. NREL/CP-620-39683. National Renewable Energy

Laboratory. April 2006.

E3: Energy and Environmental Economics. "Methodology and Forecast of Long Term Avoided Costs for the Evaluation of California Energy Efficiency Programs." Prepared for the Public Utilities Commission of the State of California. October 2004.

Energy Information Administration. "Impacts of a 10-percent Renewable Portfolio Standard." Report Number SR/OIAF/2002-03. 2002 and 2003.

Energy Information Administration. Residential Energy Consumption Survey 2001. Available at www.eia.doe.gov/emeu/recs/recs2001/enduse2001/enduse2001.html.

Energy Information Administration. "Electric Power Annual 2004.” 2005.

Energy Information Administration. "Renewable Energy Annual 2004.” June 2006.

Energy Information Administration. Natural Gas: U.S. Data. Available at:

www.eia.doe.gov/oil_gas/natural_gas/info glance/natural gas.html.

Energy Information Administration. "Annual Energy Outlook 2007 (Early Release)" Data for Figure 5. Available at: www.eia.doc.gov/oiaf/aeo/electricity.html.

Energy Information Administration. "Annual Energy Outlook 2007 (Early Release)” Data for Figure 3. Available at: www.eia.doe.gov/oiaf/aeo/consumption.html. 
Environmental Protection Agency. "Technical Addendum: Methodologies for the Benefit Analysis of the Clear Skies Act of 2003." September 2003.

Gellings, C. W., and Yeager, K. "Transforming the Electric Infrastructure.” Physics Today. December 2004.

Hadley, S.W. and J.W. Van Dyke, W.P. Poore, T.K. Stovall. "Quantitative Assessment of the Distributed Energy Resource Benefits.” U.S. Department of Energy Oak Ridge National Laboratory. May 2003.

Hoff, T.E., Perez, R., Margolis, R.M. "Maximizing the Value of Customer-Sited PV Systems Using Storage and Controls." Proceedings of the ASES 34h Annual Conference. 2005.

ICF Consulting. "The Economic Cost of the Blackout-An issue paper on the Northeastern Blackout, August 14, 2003”. Issue Paper. Fall 2003.

"Interim Opinion on E3 Avoided Cost Methodology." Decision 05-04-024 before the Public Utilities Commission of the State of California. April 7, 2005.

Itron, Inc. "CPUC Self-Generation Incentive Program Preliminary Cost-Effectiveness Evaluation Report." Submitted to the California Public Utilities Commission: Energy Division. September 2005.

Itron, Inc. "Framework for Assessing the Cost-Effectiveness of the Self-Generation Incentive Program." Prepared for the California Public Utilities Commission. March 2005.

Margolis, Robert. “The Solar America Initiative: Energy, Economic and Environmental Benefits.” Draft White Paper Prepared for the National Renewable Energy Laboratory. September 2006.

Perez, R. and R. Margolis, M. Kmiecik, M. Schwab, M. Perez. "Update: Effective Load Carrying Capability of Photovoltaics in the United States." Prepared for the American Solar Energy Society Solar 2006 Conference, Denver, CO, July 2006. NREL/CP-620-40068. National Renewable Energy

Laboratory. June 2006.

Perez, R., Kmiecik, M., Hoff, T., Herig, C., Letendre, S., Williams, J., and Margolis, R. "Availability of Dispersed Photovoltaic Resource During the August $14^{\text {th }} 2003$ Northeast Power Outage." Proc. ASES

Natl. Conference. 2004.

Union of Concerned Scientists. "Renewable Energy can help Alleviate Natural Gas Crisis: A National Renewable Electricity Standard Conserves Natural Gas, Reduces Natural Gas Prices, and Can Save Consumers and Businesses Money." Fact Sheet, June 2003.

U.S. Climate Change Technology Program. "Technology Options for the Near and Long Term." Section 1.3.2: Transmission and Distribution Technologies. Page 34. November 2003.

Wiser, Ryan and Mark Bollinger and Matthew St. Clair. "Easing the Natural Gas Crisis: Reducing Natural Gas Prices through Increased Deployment of Renewable Energy and Energy Efficiency." Lawrence Berkeley National Laboratory: Environmental Energy Technologies Division. 2005.

Wiser, Ryan and Mark Bollinger and Matthew St. Clair. "Putting Downward Pressure on Natural Gas Prices: The Impact of Renewable Energy and Energy Efficiency." Lawrence Berkeley National Laboratory. 2004(a). 
Wiser, Ryan and Mark Bollinger. "The Value of Renewable Energy as a Hedge Against Fuel Price Risk." Lawrence Berkeley National Laboratory. 2004(b).

Woo, CK and R. Orans and B. Horii and R. Pupp and G. Heffner. "Area- and Time-Specific Marginal Capacity Costs of Electricity Distribution." Energy: The International Journal. Volume 19(12): 12131218. 1994.

Young, William. "Assuring Power in a Disaster and Providing Energy Security." Proceedings of ASES Annual Conference. July 2004. 


\section{APPENDIX A: DetAILED IMPLAN MOdEL ResultS}

The following tables show the annual net benefits (relative to the counterfactual scenario) for each of the IMPLAN benefit categories of output, personal income, jobs, and tax revenues. For these tables, the total impacts are shown which are the sum of the direct, indirect, and induced effects discussed in the main body of the report.

For each year, the construction impacts are calculated based only the PV installations done in that year. Similarly, the R\&D impacts reflect only the R\&D spending for the individual year. For O\&M expenses, these continue to accrue for each the PV system is installed. Therefore, the economic impacts are

calculated based on the total installed capacity for that year. For example, the O\&M benefits in 2015 are calculated based on the total installed capacity of $5 \mathrm{GW}$ (low scenario) and $10 \mathrm{GW}$ (high scenario). 
Table 23: Annual Construction Impacts - High Scenario

\begin{tabular}{cccccc}
\hline Year & $\begin{array}{c}\text { Total Annual } \\
\text { Installed Capacity } \\
\text { (GW) - High }\end{array}$ & $\begin{array}{c}\text { SAI Induced } \\
\text { Installed Capacity } \\
\text { (GW) - High }\end{array}$ & $\begin{array}{c}\text { Construction } \\
\text { Total Output }\end{array}$ & $\begin{array}{c}\text { Construction } \\
\text { Total Personal } \\
\text { Income }\end{array}$ & $\begin{array}{c}\text { Construction } \\
\text { Total Jobs }\end{array}$ \\
\hline $\mathbf{2 0 0 5}$ & $\mathbf{0 . 1 1}$ & 0.11 & $\$ 1,009,491,000$ & $\$ 348,085,000$ & 3,450 \\
$\mathbf{2 0 0 6}$ & $\mathbf{0 . 1 5}$ & 0.15 & $\$ 1,251,959,000$ & $\$ 431,356,000$ & 4,290 \\
$\mathbf{2 0 0 7}$ & $\mathbf{0 . 2 1}$ & 0.20 & $\$ 1,552,160,000$ & $\$ 534,336,000$ & 5,310 \\
$\mathbf{2 0 0 8}$ & $\mathbf{0 . 2 9}$ & 0.28 & $\$ 1,923,660,000$ & $\$ 661,604,000$ & 6,580 \\
$\mathbf{2 0 0 9}$ & $\mathbf{0 . 4 0}$ & 0.38 & $\$ 2,383,135,000$ & $\$ 818,782,000$ & 8,140 \\
$\mathbf{2 0 1 0}$ & $\mathbf{0 . 5 5}$ & 0.51 & $\$ 2,951,074,000$ & $\$ 1,012,754,000$ & 10,070 \\
$\mathbf{2 0 1 1}$ & $\mathbf{0 . 7 6}$ & 0.69 & $\$ 3,652,613,000$ & $\$ 1,251,931,000$ & 12,450 \\
$\mathbf{2 0 1 2}$ & $\mathbf{1 . 0 4}$ & 0.94 & $\$ 4,518,531,000$ & $\$ 1,546,564,000$ & 15,390 \\
$\mathbf{2 0 1 3}$ & $\mathbf{1 . 4 4}$ & 1.28 & $\$ 5,586,461,000$ & $\$ 1,909,128,000$ & 19,020 \\
$\mathbf{2 0 1 4}$ & $\mathbf{1 . 9 9}$ & 1.75 & $\$ 6,902,320,000$ & $\$ 2,354,770,000$ & 23,460 \\
$\mathbf{2 0 1 5}$ & $\mathbf{2 . 7 4}$ & 2.37 & $\$ 8,522,000,000$ & $\$ 2,901,796,000$ & 28,940 \\
$\mathbf{2 0 1 6}$ & $\mathbf{2 . 9 9}$ & 2.57 & $\$ 9,038,166,000$ & $\$ 3,076,249,000$ & 30,680 \\
$\mathbf{2 0 1 7}$ & $\mathbf{3 . 2 7}$ & 2.78 & $\$ 9,585,255,000$ & $\$ 3,261,040,000$ & 32,530 \\
$\mathbf{2 0 1 8}$ & $\mathbf{3 . 5 8}$ & 3.01 & $\$ 10,165,089,000$ & $\$ 3,456,772,000$ & 34,490 \\
$\mathbf{2 0 1 9}$ & $\mathbf{3 . 9 1}$ & 3.26 & $\$ 10,779,599,000$ & $\$ 3,664,077,000$ & 36,560 \\
$\mathbf{2 0 2 0}$ & $\mathbf{4 . 2 7}$ & 3.52 & $\$ 11,430,825,000$ & $\$ 3,883,629,000$ & 38,760 \\
$\mathbf{2 0 2 1}$ & $\mathbf{4 . 6 7}$ & 3.81 & $\$ 12,120,921,000$ & $\$ 4,116,131,000$ & 41,090 \\
$\mathbf{2 0 2 2}$ & $\mathbf{5 . 1 0}$ & 4.13 & $\$ 12,852,168,000$ & $\$ 4,362,333,000$ & 43,560 \\
$\mathbf{2 0 2 3}$ & $\mathbf{5 . 5 8}$ & 4.47 & $\$ 13,626,979,000$ & $\$ 4,623,016,000$ & 46,160 \\
$\mathbf{2 0 2 4}$ & $\mathbf{6 . 1 0}$ & 4.84 & $\$ 14,447,899,000$ & $\$ 4,899,021,000$ & 48,930 \\
$\mathbf{2 0 2 5}$ & $\mathbf{6 . 6 7}$ & 5.23 & $\$ 15,317,622,000$ & $\$ 5,191,221,000$ & 51,850 \\
$\mathbf{2 0 2 6}$ & $\mathbf{7 . 2 9}$ & 5.66 & $\$ 16,238,995,000$ & $\$ 5,500,542,000$ & 54,950 \\
$\mathbf{2 0 2 7}$ & $\mathbf{7 . 9 6}$ & 6.13 & $\$ 17,215,025,000$ & $\$ 5,827,962,000$ & 58,230 \\
$\mathbf{2 0 2 8}$ & $\mathbf{8 . 7 0}$ & 6.63 & $\$ 18,248,885,000$ & $\$ 6,174,512,000$ & 61,710 \\
$\mathbf{2 0 2 9}$ & $\mathbf{9 . 5 1}$ & 7.18 & $\$ 19,343,936,000$ & $\$ 6,541,273,000$ & 65,380 \\
$\mathbf{2 0 3 0}$ & $\mathbf{1 0 . 4 0}$ & 7.77 & $\$ 20,503,720,000$ & $\$ 6,929,398,000$ & 69,280 \\
\hline & & & & & \\
\end{tabular}


Table 24: Annual Construction Impacts - Low Scenario

\begin{tabular}{cccccc}
\hline Year & $\begin{array}{c}\text { Total Annual } \\
\text { Installed Capacity } \\
\text { (GW) - Low }\end{array}$ & $\begin{array}{c}\text { SAI Induced } \\
\text { Installed Capacity } \\
\text { (GW) - Low }\end{array}$ & $\begin{array}{c}\text { Construction } \\
\text { Total Output }\end{array}$ & $\begin{array}{c}\text { Construction } \\
\text { Total Personal } \\
\text { Income }\end{array}$ & $\begin{array}{c}\text { Construction } \\
\text { Total Jobs }\end{array}$ \\
\hline $\mathbf{2 0 0 5}$ & 0.11 & 0.11 & $\$ 1,009,491,000$ & $\$ 348,085,000$ & 3,450 \\
$\mathbf{2 0 0 6}$ & 0.14 & 0.13 & $\$ 1,111,096,000$ & $\$ 382,823,000$ & 3,800 \\
$\mathbf{2 0 0 7}$ & 0.17 & 0.16 & $\$ 1,222,532,000$ & $\$ 420,860,000$ & 4,180 \\
$\mathbf{2 0 0 8}$ & 0.21 & 0.19 & $\$ 1,344,662,000$ & $\$ 462,470,000$ & 4,600 \\
$\mathbf{2 0 0 9}$ & 0.27 & 0.23 & $\$ 1,478,411,000$ & $\$ 507,944,000$ & 5,050 \\
$\mathbf{2 0 1 0}$ & 0.34 & 0.28 & $\$ 1,624,756,000$ & $\$ 557,587,000$ & 5,550 \\
$\mathbf{2 0 1 1}$ & 0.42 & 0.34 & $\$ 1,784,734,000$ & $\$ 611,717,000$ & 6,090 \\
$\mathbf{2 0 1 2}$ & 0.52 & 0.41 & $\$ 1,959,426,000$ & $\$ 670,656,000$ & 6,680 \\
$\mathbf{2 0 1 3}$ & 0.65 & 0.49 & $\$ 2,149,958,000$ & $\$ 734,731,000$ & 7,310 \\
$\mathbf{2 0 1 4}$ & 0.82 & 0.60 & $\$ 2,357,491,000$ & $\$ 804,273,000$ & 8,010 \\
$\mathbf{2 0 1 5}$ & 1.02 & 0.72 & $\$ 2,583,200,000$ & $\$ 879,597,000$ & 8,770 \\
$\mathbf{2 0 1 6}$ & 1.19 & 0.85 & $\$ 2,982,955,000$ & $\$ 1,015,284,000$ & 10,130 \\
$\mathbf{2 0 1 7}$ & 1.39 & 1.00 & $\$ 3,444,452,000$ & $\$ 1,171,852,000$ & 11,690 \\
$\mathbf{2 0 1 8}$ & 1.62 & 1.18 & $\$ 3,977,201,000$ & $\$ 1,352,498,000$ & 13,500 \\
$\mathbf{2 0 1 9}$ & 1.89 & 1.39 & $\$ 4,592,181,000$ & $\$ 1,560,922,000$ & 15,570 \\
$\mathbf{2 0 2 0}$ & 2.21 & 1.63 & $\$ 5,302,050,000$ & $\$ 1,801,375,000$ & 17,980 \\
$\mathbf{2 0 2 1}$ & 2.57 & 1.93 & $\$ 6,121,415,000$ & $\$ 2,078,765,000$ & 20,750 \\
$\mathbf{2 0 2 2}$ & 3.00 & 2.27 & $\$ 7,067,122,000$ & $\$ 2,398,748,000$ & 23,950 \\
$\mathbf{2 0 2 3}$ & 3.50 & 2.68 & $\$ 8,158,602,000$ & $\$ 2,767,845,000$ & 27,630 \\
$\mathbf{2 0 2 4}$ & 4.09 & 3.15 & $\$ 9,418,263,000$ & $\$ 3,193,563,000$ & 31,890 \\
$\mathbf{2 0 2 5}$ & 4.77 & 3.71 & $\$ 10,871,949,000$ & $\$ 3,684,560,000$ & 36,810 \\
$\mathbf{2 0 2 6}$ & 5.56 & 4.38 & $\$ 12,549,465,000$ & $\$ 4,250,809,000$ & 42,460 \\
$\mathbf{2 0 2 7}$ & 6.49 & 5.16 & $\$ 14,485,171,000$ & $\$ 4,903,800,000$ & 49,000 \\
$\mathbf{2 0 2 8}$ & 7.57 & 6.08 & $\$ 16,718,693,000$ & $\$ 5,656,770,000$ & 56,540 \\
$\mathbf{2 0 2 9}$ & 8.83 & 7.16 & $\$ 19,295,710,000$ & $\$ 6,524,967,000$ & 65,220 \\
$\mathbf{2 0 3 0}$ & 10.31 & 8.44 & $\$ 22,268,889,000$ & $\$ 7,525,950,000$ & 75,230 \\
\hline
\end{tabular}


Table 25: Annual O\&M Impacts - High Scenario

\begin{tabular}{cccccc}
\hline Year & $\begin{array}{c}\text { Total } \\
\text { Cummulative } \\
\text { Installed Capacity } \\
\text { High }\end{array}$ & $\begin{array}{c}\text { SAI Induced } \\
\text { Cummulative } \\
\text { Installed Capacity } \\
\text { High }\end{array}$ & $\begin{array}{c}\text { O\&M Total } \\
\text { Output }\end{array}$ & $\begin{array}{c}\text { O\&M } \\
\text { Total Personal } \\
\text { Income }\end{array}$ & $\begin{array}{c}\text { O\&M Total } \\
\text { Jobs }\end{array}$ \\
\hline $\mathbf{2 0 0 5}$ & 0.44 & 0.44 & $\$ 51,601,000$ & $\$ 28,364,000$ & 980 \\
$\mathbf{2 0 0 6}$ & 0.59 & 0.59 & $\$ 64,067,000$ & $\$ 35,934,000$ & 1,270 \\
$\mathbf{2 0 0 7}$ & 0.80 & 0.79 & $\$ 79,920,000$ & $\$ 45,781,000$ & 1,650 \\
$\mathbf{2 0 0 8}$ & 1.09 & 1.07 & $\$ 100,077,000$ & $\$ 58,597,000$ & 2,160 \\
$\mathbf{2 0 0 9}$ & 1.49 & 1.45 & $\$ 125,720,000$ & $\$ 75,302,000$ & 2,840 \\
$\mathbf{2 0 1 0}$ & 2.04 & 1.96 & $\$ 158,361,000$ & $\$ 97,109,000$ & 3,740 \\
$\mathbf{2 0 1 1}$ & 2.79 & 2.65 & $\$ 199,955,000$ & $\$ 125,619,000$ & 4,930 \\
$\mathbf{2 0 1 2}$ & 3.84 & 3.60 & $\$ 253,016,000$ & $\$ 162,960,000$ & 6,540 \\
$\mathbf{2 0 1 3}$ & 5.28 & 4.88 & $\$ 320,800,000$ & $\$ 211,949,000$ & 8,660 \\
$\mathbf{2 0 1 4}$ & 7.26 & 6.63 & $\$ 407,511,000$ & $\$ 276,331,000$ & 11,520 \\
$\mathbf{2 0 1 5}$ & 10.00 & 9.00 & $\$ 518,614,000$ & $\$ 361,094,000$ & 15,330 \\
$\mathbf{2 0 1 6}$ & 12.99 & 11.57 & $\$ 657,780,000$ & $\$ 460,551,000$ & 19,630 \\
$\mathbf{2 0 1 7}$ & 16.26 & 14.35 & $\$ 805,054,000$ & $\$ 566,828,000$ & 24,250 \\
$\mathbf{2 0 1 8}$ & 19.84 & 17.36 & $\$ 961,035,000$ & $\$ 680,454,000$ & 29,230 \\
$\mathbf{2 0 1 9}$ & 23.75 & 20.62 & $\$ 1,126,362,000$ & $\$ 802,008,000$ & 34,590 \\
$\mathbf{2 0 2 0}$ & 28.02 & 24.14 & $\$ 1,301,720,000$ & $\$ 932,103,000$ & 40,340 \\
$\mathbf{2 0 2 1}$ & 32.69 & 27.96 & $\$ 1,487,844,000$ & $\$ 1,071,407,000$ & 46,540 \\
$\mathbf{2 0 2 2}$ & 37.79 & 32.08 & $\$ 1,685,518,000$ & $\$ 1,220,635,000$ & 53,220 \\
$\mathbf{2 0 2 3}$ & 43.37 & 36.55 & $\$ 1,895,586,000$ & $\$ 1,380,562,000$ & 60,420 \\
$\mathbf{2 0 2 4}$ & 49.47 & 41.39 & $\$ 2,118,949,000$ & $\$ 1,552,014,000$ & 68,170 \\
$\mathbf{2 0 2 5}$ & 56.14 & 46.62 & $\$ 2,356,573,000$ & $\$ 1,735,897,000$ & 76,520 \\
$\mathbf{2 0 2 6}$ & 63.42 & 52.29 & $\$ 2,609,495,000$ & $\$ 1,933,169,000$ & 85,520 \\
$\mathbf{2 0 2 7}$ & 71.38 & 58.42 & $\$ 2,878,827,000$ & $\$ 2,144,876,000$ & 95,220 \\
$\mathbf{2 0 2 8}$ & 80.09 & 65.05 & $\$ 3,165,756,000$ & $\$ 2,372,139,000$ & 105,680 \\
$\mathbf{2 0 2 9}$ & 89.60 & 72.23 & $\$ 3,471,563,000$ & $\$ 2,616,166,000$ & 116,950 \\
$\mathbf{2 0 3 0}$ & 100.00 & 80.00 & $\$ 3,797,614,000$ & $\$ 2,878,265,000$ & 129,120 \\
\hline & & & & & \\
\hline
\end{tabular}


Table 26: Annual O\&M Impacts - Low Scenario

\begin{tabular}{|c|c|c|c|c|c|}
\hline Year & $\begin{array}{c}\text { Total } \\
\text { Cummulative } \\
\text { Installed Capacity - } \\
\text { Low }\end{array}$ & $\begin{array}{c}\text { SAI Induced } \\
\text { Cummulative } \\
\text { Installed Capacity - } \\
\text { Low }\end{array}$ & $\begin{array}{l}\text { O\&M Total } \\
\text { Output }\end{array}$ & $\begin{array}{c}\text { O\&M } \\
\text { Total Personal } \\
\text { Income }\end{array}$ & $\begin{array}{c}\text { O\&M Total } \\
\text { Jobs }\end{array}$ \\
\hline 2005 & 0.44 & 0.44 & $\$ 51,601,000$ & $\$ 28,364,000$ & 980 \\
\hline 2006 & 0.58 & 0.57 & $\$ 62,239,000$ & $\$ 34,908,000$ & 1,240 \\
\hline 2007 & 0.75 & 0.73 & $\$ 73,872,000$ & $\$ 42,315,000$ & 1,530 \\
\hline 2008 & 0.96 & 0.93 & $\$ 86,674,000$ & $\$ 50,748,000$ & 1,870 \\
\hline 2009 & 1.23 & 1.16 & $\$ 100,848,000$ & $\$ 60,404,000$ & 2,280 \\
\hline 2010 & 1.57 & 1.44 & $\$ 116,624,000$ & $\$ 71,516,000$ & 2,760 \\
\hline 2011 & 1.99 & 1.78 & $\$ 134,268,000$ & $\$ 84,353,000$ & 3,310 \\
\hline 2012 & 2.51 & 2.19 & $\$ 154,089,000$ & $\$ 99,244,000$ & 3,970 \\
\hline 2013 & 3.16 & 2.68 & $\$ 176,444,000$ & $\$ 116,575,000$ & 4,770 \\
\hline 2014 & 3.98 & 3.28 & $\$ 201,750,000$ & $\$ 136,805,000$ & 5,700 \\
\hline 2015 & 5.00 & 4.00 & $\$ 230,495,000$ & $\$ 160,486,000$ & 6,810 \\
\hline 2016 & 6.19 & 4.85 & $\$ 275,635,000$ & $\$ 192,987,000$ & 8,230 \\
\hline 2017 & 7.58 & 5.85 & $\$ 328,036,000$ & $\$ 230,966,000$ & 9,890 \\
\hline 2018 & 9.20 & 7.02 & $\$ 388,893,000$ & $\$ 275,353,000$ & 11,830 \\
\hline 2019 & 11.09 & 8.41 & $\$ 459,593,000$ & $\$ 327,246,000$ & 14,100 \\
\hline 2020 & 13.30 & 10.05 & $\$ 541,752,000$ & $\$ 387,925,000$ & 16,790 \\
\hline 2021 & 15.87 & 11.97 & $\$ 637,251,000$ & $\$ 458,889,000$ & 19,940 \\
\hline 2022 & 18.87 & 14.24 & $\$ 748,284,000$ & $\$ 541,900,000$ & 23,620 \\
\hline 2023 & 22.38 & 16.92 & $\$ 877,405,000$ & $\$ 639,015,000$ & 27,960 \\
\hline 2024 & 26.46 & 20.07 & $\$ 1,027,585,000$ & $\$ 752,652,000$ & 33,060 \\
\hline 2025 & 31.23 & 23.79 & $\$ 1,202,294,000$ & $\$ 885,634,000$ & 39,030 \\
\hline 2026 & 36.80 & 28.16 & $\$ 1,405,567,000$ & $\$ 1,041,274,000$ & 46,060 \\
\hline 2027 & 43.29 & 33.32 & $\$ 1,642,109,000$ & $\$ 1,223,457,000$ & 54,320 \\
\hline 2028 & 50.86 & 39.40 & $\$ 1,917,403,000$ & $\$ 1,436,732,000$ & 64,010 \\
\hline 2029 & 59.69 & 46.56 & $\$ 2,237,837,000$ & $\$ 1,686,431,000$ & 75,400 \\
\hline 2030 & 70.00 & 55.00 & $\$ 2,610,859,000$ & $\$ 1,978,806,000$ & 88,770 \\
\hline
\end{tabular}


Table 27: Annual R\&D Impacts - High and Low Scenarios

\begin{tabular}{ccccc}
\hline Year & $\begin{array}{c}\text { Annual R\&D } \\
\text { Spending }\end{array}$ & R\&D Total Output & $\begin{array}{c}\text { R\&D } \\
\text { Total Personal } \\
\text { Income }\end{array}$ & $\begin{array}{c}\text { R\&D Total } \\
\text { Jobs }\end{array}$ \\
\hline $\mathbf{2 0 0 5}$ & $\$ 148,000,000$ & $\$ 118,007,000$ & $\$ 64,254,000$ & 910 \\
$\mathbf{2 0 0 6}$ & $\$ 148,000,000$ & $\$ 118,007,000$ & $\$ 64,254,000$ & 910 \\
$\mathbf{2 0 0 7}$ & $\$ 148,000,000$ & $\$ 118,007,000$ & $\$ 64,254,000$ & 910 \\
$\mathbf{2 0 0 8}$ & $\$ 148,000,000$ & $\$ 118,007,000$ & $\$ 64,254,000$ & 910 \\
$\mathbf{2 0 0 9}$ & $\$ 148,000,000$ & $\$ 118,007,000$ & $\$ 64,254,000$ & 910 \\
$\mathbf{2 0 1 0}$ & $\$ 148,000,000$ & $\$ 118,007,000$ & $\$ 64,254,000$ & 910 \\
$\mathbf{2 0 1 1}$ & $\$ 148,000,000$ & $\$ 118,007,000$ & $\$ 64,254,000$ & 910 \\
$\mathbf{2 0 1 2}$ & $\$ 148,000,000$ & $\$ 118,007,000$ & $\$ 64,254,000$ & 910 \\
$\mathbf{2 0 1 3}$ & $\$ 148,000,000$ & $\$ 118,007,000$ & $\$ 64,254,000$ & 910 \\
$\mathbf{2 0 1 4}$ & $\$ 148,000,000$ & $\$ 118,007,000$ & $\$ 64,254,000$ & 910 \\
$\mathbf{2 0 1 5}$ & $\$ 148,000,000$ & $\$ 118,007,000$ & $\$ 64,254,000$ & 910 \\
\hline
\end{tabular}


Table 28: Annual Tax Impacts - Construction

\begin{tabular}{|c|c|c|c|c|c|c|}
\hline \multirow[b]{2}{*}{ Year } & \multicolumn{3}{|c|}{ High Scenario } & \multicolumn{3}{|c|}{ Low Scenario } \\
\hline & $\begin{array}{c}\text { Total Federal } \\
\text { Taxes - } \\
\text { Construction }\end{array}$ & $\begin{array}{l}\text { Total State and } \\
\text { Local Taxes - } \\
\text { Construction }\end{array}$ & $\begin{array}{l}\text { Total Taxes - } \\
\text { Construction }\end{array}$ & $\begin{array}{l}\text { Total Federal } \\
\text { Taxes - } \\
\text { Construction }\end{array}$ & $\begin{array}{c}\text { Total State and } \\
\text { Local Taxes - } \\
\text { Construction }\end{array}$ & $\begin{array}{l}\text { Total Taxes - } \\
\text { Construction }\end{array}$ \\
\hline 2005 & $\$ 73,543,590$ & $\$ 14,513,980$ & $\$ 88,057,570$ & $\$ 73,543,590$ & $\$ 14,513,980$ & $\$ 88,057,570$ \\
\hline 2006 & $\$ 91,206,530$ & $\$ 18,077,390$ & $\$ 109,283,920$ & $\$ 80,944,540$ & $\$ 16,043,450$ & $\$ 96,987,990$ \\
\hline 2007 & $\$ 113,074,630$ & $\$ 22,517,600$ & $\$ 135,592,230$ & $\$ 89,061,180$ & $\$ 17,735,580$ & $\$ 106,796,760$ \\
\hline 2008 & $\$ 140,135,530$ & $\$ 28,050,970$ & $\$ 168,186,500$ & $\$ 97,956,490$ & $\$ 19,607,990$ & $\$ 117,564,480$ \\
\hline 2009 & $\$ 173,603,900$ & $\$ 34,947,640$ & $\$ 208,551,540$ & $\$ 107,697,600$ & $\$ 21,680,230$ & $\$ 129,377,830$ \\
\hline 2010 & $\$ 214,971,580$ & $\$ 43,544,600$ & $\$ 258,516,180$ & $\$ 118,355,740$ & $\$ 23,974,120$ & $\$ 142,329,860$ \\
\hline 2011 & $\$ 266,068,490$ & $\$ 54,262,860$ & $\$ 320,331,350$ & $\$ 130,006,010$ & $\$ 26,513,840$ & $\$ 156,519,850$ \\
\hline 2012 & $\$ 329,135,610$ & $\$ 67,628,090$ & $\$ 396,763,700$ & $\$ 142,727,110$ & $\$ 29,326,390$ & $\$ 172,053,500$ \\
\hline 2013 & $\$ 406,912,310$ & $\$ 84,297,110$ & $\$ 491,209,420$ & $\$ 156,600,830$ & $\$ 32,441,870$ & $\$ 189,042,700$ \\
\hline 2014 & $\$ 502,740,750$ & $\$ 105,090,860$ & $\$ 607,831,610$ & $\$ 171,711,330$ & $\$ 35,893,820$ & $\$ 207,605,150$ \\
\hline 2015 & $\$ 620,688,860$ & $\$ 131,035,690$ & $\$ 751,724,550$ & $\$ 188,144,040$ & $\$ 39,719,710$ & $\$ 227,863,750$ \\
\hline 2016 & $\$ 658,277,500$ & $\$ 139,275,510$ & $\$ 797,553,010$ & $\$ 217,257,850$ & $\$ 45,966,490$ & $\$ 263,224,340$ \\
\hline 2017 & $\$ 698,117,570$ & $\$ 148,034,680$ & $\$ 846,152,250$ & $\$ 250,867,840$ & $\$ 53,196,130$ & $\$ 304,063,970$ \\
\hline 2018 & $\$ 740,341,760$ & $\$ 157,346,050$ & $\$ 897,687,810$ & $\$ 289,666,740$ & $\$ 61,563,350$ & $\$ 351,230,090$ \\
\hline 2019 & $\$ 785,090,470$ & $\$ 167,244,460$ & $\$ 952,334,930$ & $\$ 334,453,730$ & $\$ 71,247,260$ & $\$ 405,700,990$ \\
\hline 2020 & $\$ 832,512,150$ & $\$ 177,767,090$ & $\$ 1,010,279,240$ & $\$ 386,150,750$ & $\$ 82,455,110$ & $\$ 468,605,860$ \\
\hline 2021 & $\$ 882,763,780$ & $\$ 188,953,420$ & $\$ 1,071,717,200$ & $\$ 445,821,260$ & $\$ 95,426,950$ & $\$ 541,248,210$ \\
\hline 2022 & $\$ 936,011,280$ & $\$ 200,845,430$ & $\$ 1,136,856,710$ & $\$ 514,691,860$ & $\$ 110,440,450$ & $\$ 625,132,310$ \\
\hline 2023 & $\$ 992,430,090$ & $\$ 213,487,800$ & $\$ 1,205,917,890$ & $\$ 594,177,350$ & $\$ 127,817,200$ & $\$ 721,994,550$ \\
\hline 2024 & $\$ 1,052,205,610$ & $\$ 226,928,020$ & $\$ 1,279,133,630$ & $\$ 685,909,390$ & $\$ 147,929,340$ & $\$ 833,838,730$ \\
\hline 2025 & $\$ 1,115,533,850$ & $\$ 241,216,630$ & $\$ 1,356,750,480$ & $\$ 791,769,670$ & $\$ 171,207,730$ & $\$ 962,977,400$ \\
\hline 2026 & $\$ 1,182,621,900$ & $\$ 256,407,330$ & $\$ 1,439,029,230$ & $\$ 913,927,970$ & $\$ 198,151,110$ & $\$ 1,112,079,080$ \\
\hline 2027 & $\$ 1,253,688,540$ & $\$ 272,557,320$ & $\$ 1,526,245,860$ & $\$ 1,054,886,330$ & $\$ 229,336,870$ & $\$ 1,284,223,200$ \\
\hline 2028 & $\$ 1,328,964,960$ & $\$ 289,727,320$ & $\$ 1,618,692,280$ & $\$ 1,217,529,520$ & $\$ 265,433,320$ & $\$ 1,482,962,840$ \\
\hline 2029 & $\$ 1,408,695,320$ & $\$ 307,982,060$ & $\$ 1,716,677,380$ & $\$ 1,405,183,360$ & $\$ 307,214,260$ & $\$ 1,712,397,620$ \\
\hline 2030 & $\$ 1,493,137,530$ & $\$ 327,390,310$ & $\$ 1,820,527,840$ & $\$ 1,621,681,990$ & $\$ 355,575,390$ & $\$ 1,977,257,380$ \\
\hline
\end{tabular}


Table 29: Annual Tax Impacts - O\&M

\begin{tabular}{|c|c|c|c|c|c|c|}
\hline \multirow[b]{2}{*}{ Year } & \multicolumn{3}{|c|}{ High Scenario } & \multicolumn{3}{|c|}{$\begin{array}{l}\text { Low Scenario } \\
\text { Total State and }\end{array}$} \\
\hline & $\begin{array}{l}\text { Total Federal } \\
\text { Taxes - O\&M }\end{array}$ & $\begin{array}{l}\text { Total State and } \\
\text { Local Taxes - } \\
\text { O\&M }\end{array}$ & $\begin{array}{c}\text { Total Taxes - } \\
\text { O\&M }\end{array}$ & $\begin{array}{l}\text { Total Federal } \\
\text { Taxes - O\&M }\end{array}$ & $\begin{array}{l}\text { Total State and } \\
\text { Local Taxes - } \\
\text { O\&M }\end{array}$ & $\begin{array}{c}\text { Total Taxes - } \\
\text { O\&M }\end{array}$ \\
\hline 2005 & $-\$ 3,249,310$ & $\$ 1,509,210$ & $-\$ 1,740,100$ & $-\$ 3,249,310$ & $\$ 1,509,210$ & $-\$ 1,740,100$ \\
\hline 2006 & $-\$ 4,802,490$ & $\$ 1,781,260$ & $-\$ 3,021,230$ & $-\$ 4,665,430$ & $\$ 1,730,420$ & $-\$ 2,935,010$ \\
\hline 2007 & $-\$ 7,011,170$ & $\$ 2,099,080$ & $-\$ 4,912,090$ & $-\$ 6,480,560$ & $\$ 1,940,210$ & $-\$ 4,540,350$ \\
\hline 2008 & $-\$ 10,137,550$ & $\$ 2,464,930$ & $-\$ 7,672,620$ & $-\$ 8,779,820$ & $\$ 2,134,820$ & $-\$ 6,645,000$ \\
\hline 2009 & $-\$ 14,544,140$ & $\$ 2,878,580$ & $-\$ 11,665,560$ & $-\$ 11,666,830$ & $\$ 2,309,120$ & $-\$ 9,357,710$ \\
\hline 2010 & $-\$ 20,731,720$ & $\$ 3,335,520$ & $-\$ 17,396,200$ & $-\$ 15,267,720$ & $\$ 2,456,420$ & $-\$ 12,811,300$ \\
\hline 2011 & $-\$ 29,390,800$ & $\$ 3,824,490$ & $-\$ 25,566,310$ & $-\$ 19,735,690$ & $\$ 2,568,080$ & $-\$ 17,167,610$ \\
\hline 2012 & $-\$ 41,472,160$ & $\$ 4,323,570$ & $-\$ 37,148,590$ & $-\$ 25,256,790$ & $\$ 2,633,060$ & $-\$ 22,623,730$ \\
\hline 2013 & $-\$ 58,283,630$ & $\$ 4,795,070$ & $-\$ 53,488,560$ & $-\$ 32,056,750$ & $\$ 2,637,360$ & $-\$ 29,419,390$ \\
\hline 2014 & $-\$ 81,621,910$ & $\$ 5,177,610$ & $-\$ 76,444,300$ & $-\$ 40,409,230$ & $\$ 2,563,310$ & $-\$ 37,845,920$ \\
\hline 2015 & $-\$ 113,953,120$ & $\$ 5,375,250$ & $-\$ 108,577,870$ & $-\$ 50,645,820$ & $\$ 2,388,990$ & $-\$ 48,256,830$ \\
\hline 2016 & $-\$ 147,269,960$ & $\$ 6,487,760$ & $-\$ 140,782,200$ & $-\$ 61,711,670$ & $\$ 2,718,600$ & $-\$ 58,993,070$ \\
\hline 2017 & $-\$ 183,622,700$ & $\$ 7,533,260$ & $-\$ 176,089,440$ & $-\$ 74,821,060$ & $\$ 3,069,590$ & $-\$ 71,751,470$ \\
\hline 2018 & $-\$ 223,267,260$ & $\$ 8,502,900$ & $-\$ 214,764,360$ & $-\$ 90,347,640$ & $\$ 3,440,800$ & $-\$ 86,906,840$ \\
\hline 2019 & $-\$ 266,481,150$ & $\$ 9,386,860$ & $-\$ 257,094,290$ & $-\$ 108,733,220$ & $\$ 3,830,150$ & $-\$ 104,903,070$ \\
\hline 2020 & $-\$ 313,565,400$ & $\$ 10,174,060$ & $-\$ 303,391,340$ & $-\$ 130,500,110$ & $\$ 4,234,260$ & $-\$ 126,265,850$ \\
\hline 2021 & $-\$ 364,846,510$ & $\$ 10,852,230$ & $-\$ 353,994,280$ & $-\$ 156,265,700$ & $\$ 4,648,100$ & $-\$ 151,617,600$ \\
\hline 2022 & $-\$ 420,678,480$ & $\$ 11,407,680$ & $-\$ 409,270,800$ & $-\$ 186,759,830$ & $\$ 5,064,430$ & $-\$ 181,695,400$ \\
\hline 2023 & $-\$ 481,445,240$ & $\$ 11,825,130$ & $-\$ 469,620,110$ & $-\$ 222,845,100$ & $\$ 5,473,460$ & $-\$ 217,371,640$ \\
\hline 2024 & $-\$ 547,563,070$ & $\$ 12,087,680$ & $-\$ 535,475,390$ & $-\$ 265,541,070$ & $\$ 5,861,940$ & $-\$ 259,679,130$ \\
\hline 2025 & $-\$ 619,483,400$ & $\$ 12,176,600$ & $-\$ 607,306,800$ & $-\$ 316,052,580$ & $\$ 6,212,360$ & $-\$ 309,840,220$ \\
\hline 2026 & $-\$ 697,695,620$ & $\$ 12,071,080$ & $-\$ 685,624,540$ & $-\$ 375,803,560$ & $\$ 6,501,930$ & $-\$ 369,301,630$ \\
\hline 2027 & $-\$ 782,730,380$ & $\$ 11,748,080$ & $-\$ 770,982,300$ & $-\$ 446,476,550$ & $\$ 6,701,210$ & $-\$ 439,775,340$ \\
\hline 2028 & $-\$ 875,162,990$ & $\$ 11,182,220$ & $-\$ 863,980,770$ & $-\$ 530,059,650$ & $\$ 6,772,730$ & $-\$ 523,286,920$ \\
\hline 2029 & $-\$ 975,617,070$ & $\$ 10,345,320$ & $-\$ 965,271,750$ & $-\$ 628,901,880$ & $\$ 6,668,810$ & $-\$ 622,233,070$ \\
\hline 2030 & $-\$ 1,084,768,760$ & $\$ 9,206,400$ & $-\$ 1,075,562,360$ & $-\$ 745,778,530$ & $\$ 6,329,420$ & $-\$ 739,449,110$ \\
\hline
\end{tabular}


Table 30: Annual Tax Impacts - R\&D

\begin{tabular}{|c|c|c|c|c|c|c|}
\hline \multirow[b]{2}{*}{ Year } & \multicolumn{3}{|c|}{ High Scenario } & \multicolumn{3}{|c|}{ Low Scenario } \\
\hline & $\begin{array}{l}\text { Total Federal } \\
\text { Taxes - R\&D }\end{array}$ & $\begin{array}{c}\text { Total State and } \\
\text { Local Taxes - } \\
\text { R\&D }\end{array}$ & $\begin{array}{c}\text { Total Taxes - } \\
\text { R\&D }\end{array}$ & $\begin{array}{l}\text { Total Federal } \\
\text { Taxes - R\&D }\end{array}$ & $\begin{array}{c}\text { Total State and } \\
\text { Local Taxes - } \\
\text { R\&D }\end{array}$ & $\begin{array}{c}\text { Total Taxes - } \\
\text { R\&D }\end{array}$ \\
\hline 2005 & $-\$ 2,975,790$ & $\$ 2,840,140$ & $-\$ 135,650$ & $-\$ 2,975,790$ & $\$ 2,840,140$ & $-\$ 135,650$ \\
\hline 2006 & $-\$ 2,975,790$ & $\$ 2,840,140$ & $-\$ 135,650$ & $-\$ 2,975,790$ & $\$ 2,840,140$ & $-\$ 135,650$ \\
\hline 2007 & $-\$ 2,975,790$ & $\$ 2,840,140$ & $-\$ 135,650$ & $-\$ 2,975,790$ & $\$ 2,840,140$ & $-\$ 135,650$ \\
\hline 2008 & $-\$ 2,975,790$ & $\$ 2,840,140$ & $-\$ 135,650$ & $-\$ 2,975,790$ & $\$ 2,840,140$ & $-\$ 135,650$ \\
\hline 2009 & $-\$ 2,975,790$ & $\$ 2,840,140$ & $-\$ 135,650$ & $-\$ 2,975,790$ & $\$ 2,840,140$ & $-\$ 135,650$ \\
\hline 2010 & $-\$ 2,975,790$ & $\$ 2,840,140$ & $-\$ 135,650$ & $-\$ 2,975,790$ & $\$ 2,840,140$ & $-\$ 135,650$ \\
\hline 2011 & $-\$ 2,975,790$ & $\$ 2,840,140$ & $-\$ 135,650$ & $-\$ 2,975,790$ & $\$ 2,840,140$ & $-\$ 135,650$ \\
\hline 2012 & $-\$ 2,975,790$ & $\$ 2,840,140$ & $-\$ 135,650$ & $-\$ 2,975,790$ & $\$ 2,840,140$ & $-\$ 135,650$ \\
\hline 2013 & $-\$ 2,975,790$ & $\$ 2,840,140$ & $-\$ 135,650$ & $-\$ 2,975,790$ & $\$ 2,840,140$ & $-\$ 135,650$ \\
\hline 2014 & $-\$ 2,975,790$ & $\$ 2,840,140$ & $-\$ 135,650$ & $-\$ 2,975,790$ & $\$ 2,840,140$ & $-\$ 135,650$ \\
\hline 2015 & $-\$ 2,975,790$ & $\$ 2,840,140$ & $-\$ 135,650$ & $-\$ 2,975,790$ & $\$ 2,840,140$ & $-\$ 135,650$ \\
\hline
\end{tabular}




\section{APPENDIX B: IMPLAN MOdEL TECHNICAL DETAIL}

This appendix provides a detailed discussion of the modeling tools and analysis methods used to estimate economic impacts. This appendix begins with a discussion of what economic impacts are and how they can be measured using an input-output modeling framework. It then discusses the limitations of inputoutput analysis, with recommendations on when an input-output model should be used. This appendix concludes with a discussion of the IMPLAN modeling software, which is a widely used model for estimating economic impacts.

\section{ECONOMIC IMPACTS}

Economic impacts are changes in economic activity as a result of some initial change in the economy. Although the initial stimuli can vary, economic impacts are typically measured as changes in output (or sales), income (value added), and jobs:

- Output is the broadest measure of economic activity. It represents the total value of production or, alternatively, business revenues. Output includes the costs of materials and labor, net business income (profits), and indirect business taxes.

- Income represents the total payments to workers (wages) and business owners (proprietor and corporate income). Together, wages and business income are often referred to as personal income. Corporate income represents net business income or profits. These may be reinvested or paid as dividends to shareholders. Income excludes payments from one industry to another for the purchase of intermediate goods, and is often used as a measure of the value added during production. ${ }^{25}$

- Jobs represent the number of additional jobs gained or lost as a result of some economic activity. Job impacts are the most popular measure of economic impacts because they are easy to understand.

Economic impacts often lead to changes in government revenues and expenditures. These fiscal impacts occur as changes in output, income, and jobs, lead to changes in the regional tax base and demand for government services.

\section{Gross Versus Net Economic Impacts}

Simply citing the economic impacts that occur as a result of some activity would produce an upper bound estimate of economic impacts. This upper bound estimate is often referred to as a measure of the "gross" economic impacts. Gross economic impacts offer a perspective on the magnitude of overall economic impacts that can be traced back to the activity. Gross economic impacts, however, do not accurately reflect the creation of new jobs or income as they do not take into account the jobs or income creation that would have occurred in absence of the activity being analyzed.

This problem is addressed by analyzing the "net" economic impacts of a given activity. An analysis of the net economic impacts requires that only economic stimuli that are new or additive to the local economy

\footnotetext{
${ }^{25}$ Alternatively, value added is measured as total output less purchases of intermediate goods and services. In either case, the measure of value added will be the same. However, to the extent that owners of corporations live outside the relevant study area, including corporate income will tend to overestimate the measure of value added in production.
} 
be counted. To do this, the impact analysis must include a "base case" or "counterfactual" scenario that describes what would have happened in the absence of a change in the economy.

Establishing a base case affects an analyst's ability to properly identify cause-and-effect relationships. Attributing effects to causes, and doing so only once (i.e., avoiding double counting) is essential to an evaluation of net economic impacts. In impact analysis, this base case scenario is typically implemented by positing a counterfactual argument that only counts spending that "but for" the project or activity would not have occurred.

To get a better understanding of how this base case scenario affects the impact analysis, the three components of the counterfactual argument related to a net impact analysis of a new business activity, for example, are described below:

1. Net impacts include expenditures by non-local sources that would have gone to non-local businesses but for the local presence of the new business. (The new business is an "exporter" of goods and services. In this sense, the new business brings in new spending to the community.)

2. Net impacts include expenditures by local sources that would have been spent outside of the local economy but for the local presence of the new business. (This is called "import substitution." The new business keeps local spending in the community.)

3. Net impacts would make deductions for expenditures by local sources that would have gone to other local businesses but for the new business. (This is a form of "direct substitution." The new business may actually divert spending away from other local businesses. This spending should not be included in the impact analysis.)

Net impacts are often considerably smaller than gross impacts, but provide a truer picture of the benefits from a stimulus. Using a net impact approach, the analyst is better able to answer the following question: How much better off is the local economy because of the activity or project relative to the base case alternative?

At the outset, one should decide whether the question being posed for analysis requires that net or gross impacts be determined. A common mistake is to use the results from a gross impact analysis to answer a question about the benefits or improvement to an economy due to a project or activity. This often leads to unrealistic claims about economic impacts.

\section{FEATURES OF INPUT-OUTPUT MODELS}

Input-output models serve two general purposes. First, the input-output framework is useful for organizing information about the structure of a regional economy. Using standard accounting conventions, input-output models describe the flow of commodities between producing and consuming sectors, the flow of income between businesses and institutions, and the trade in commodities between regions. In this manner, the input-output modeling framework can be used for descriptive purposes. For instance, researchers can evaluate the relative importance of various industry sectors to the local economy, e.g., the number of jobs or purchases from other local industries.

Once the information on the various transactions within an economy has been gathered and organized using the input-output framework, the data can be manipulated using a special field of mathematics called matrix algebra. This phase of input-output modeling produces "multipliers" and allows researchers to use the input-output model for prescriptive purposes. For example, a researcher can estimate the "ripple" effect that a change in one sector has on the entire economy. 


\section{Economic Linkages}

An input-output model begins with a transactions table that provides a reasonably comprehensive description of an economy and linkages between economic sectors. Table B-1 shows a hypothetical transactions table for an economy with three industry sectors. For exposition purposes, the table has been divided into four quadrants.

\section{Table B-1: A Transactions Table for a Hypothetical Economy}

\begin{tabular}{|c|c|c|c|c|c|c|c|}
\hline & \multicolumn{3}{|c|}{ INTERMEDIATE DEMANDS } & \multicolumn{3}{|c|}{ FINAL DEMANDS } & \\
\hline Seller & Agriculture & Manufacturing & Services & $\begin{array}{c}\text { Household } \\
\text { Demand }\end{array}$ & $\begin{array}{c}\text { Other } \\
\text { Demand }\end{array}$ & Exports & $\begin{array}{c}\text { Total } \\
\text { Outputs }\end{array}$ \\
\hline Agriculture & $\$ 600$ & $\$ 100$ & $\$ 400$ & $\$ 700$ & $\$ 100$ & $\$ 1,300$ & $\$ 3,200$ \\
\hline Manufacturing & $\$ 200$ & $\$ 700$ & $\$ 800$ & $\$ 1,400$ & $\$ 600$ & $\$ 300$ & $\$ 4,000$ \\
\hline Services & $\$ 200$ & $\$ 400$ & $\$ 1,500$ & $\$ 1,600$ & $\$ 200$ & $\$ 1,000$ & $\$ 4,900$ \\
\hline
\end{tabular}

\begin{tabular}{l|rrr|}
\hline Wages & $\$ 900$ & $\$ 600$ & $\$ 1,000$ \\
Other Earnings & $\$ 500$ & $\$ 400$ & $\$ 600$ \\
& $\$ 800$ & $\$ 2,200$ & $\$ 1,200$ \\
\hline Imports & $\$ 3,200$ & $\$ 4,000$ & $\$ 4,900$
\end{tabular}

The top left quadrant of the transactions table describes the production relationships between industries in the economy. This portion of the table describes the way raw materials and intermediate goods are provided by some industries ("sellers") and used by other industries ("buyers") to produce final goods and services. Because industries are buying from other industries, it describes the intermediate demands for goods and services.

The upper right quadrant of the transactions table shows who consumes the final goods and services. In this simple hypothetical transactions table, the final demand sectors consist of households, others, ${ }^{26}$ and exports. In more sophisticated input-output models, the final demand sectors are more extensive and explicitly identified in the model.

By combining the top two quadrants of the transactions table, researchers can trace the flow of goods and services from producing industries to other industries and final consumers. The sum of each row shows the total output or production of each industry. For instance, the value of total output produced by the agriculture sector is $\$ 3,200$. Of this amount, $\$ 1,100^{27}$ is used in production by other industries. The remainder is sold to final consumers - households consume $\$ 700$ worth of agricultural output; government and businesses consume $\$ 100$ worth of agricultural output; and $\$ 1,300$ of the total agricultural output is sold to entities outside of the region. The rows in the transactions table describe the "forward linkages" in an economy.

The lower left quadrant of the transactions table describes the transactions between businesses and the suppliers of factors of production. Labeled final payments, this section of the input-output model depicts

\footnotetext{
26 "Other demand" consists of government and business spending, including additions to business inventories.

${ }^{27}$ This amount represents the sum of the intermediate demands across all sectors, i.e., $\$ 600$ agriculture, $\$ 100$ manufacturing, and $\$ 400$ services.
} 
the flow of income from businesses to households (wages), others, ${ }^{28}$ and imports. The income components, excluding imports, are the elements of value added.

The left side of the transactions table shows the purchases and payments by industries to other industries and other institutions within the economy. The sum of the entries for each column represents the total purchases by that industry. The agricultural sector shows large intra-sector purchases $(\$ 600)$ from others within the agriculture sector, e.g., to produce milk the dairy must buy significant quantities of feed. Firms in the agriculture sector will also hire workers and pay wages (\$900). In addition, firms will pay taxes and earn profits $(\$ 500)$, and purchase imported goods and services $(\$ 800)$. From this example, we can trace all of the purchases for each sector of the economy. The columns in the transactions table describe the "backward linkages" in the economy.

As discussed previously, the input-output model is based on a double-entry accounting convention where inputs must be equal to outputs. Because government and businesses are implicitly included in Other Demand (government purchases, capital investment and inventories) and Other Earnings (taxes and profits), inputs must be equal to outputs. The agriculture sector of this economy produces $\$ 3,200$ in output. To do this, the agriculture sector must purchase $\$ 3,200$ in inputs from other industries, households, government, businesses and foreigners. The input-output model, thus, is a balanced or symmetrical model because total sales (outputs) of each industry equal the total purchases (inputs) by each industry.

In order to emphasize the relationships among businesses and institutions, the lower right hand quadrant of the transactions table labeled "Non-Market Transfers" has been left blank. This section of the transactions table contains information regarding inter-institutional transfers or non-market financial flows between households, businesses, government and foreigners.

\section{Economic Multipliers}

The transactions table provides a reasonably comprehensive description of the economy at a given point in time. Using annual data, it shows how much an industry produces, what it purchases, and to whom the final output is sold. It also distinguishes local from non-local sources of spending and production. In this form, the transactions table fully describes the linkages between the various sectors of the economy, but has no predictive or analytical capabilities.

The information contained in the transaction table can be expanded and then manipulated using matrix algebra to construct multipliers that measure the total impacts from a change in final demand on all industries in an economy. It is through this matrix operation that the input-output model is converted from a descriptive to a prescriptive model.

Economic impact multipliers allow researchers to follow the initial change in economic activity as it "ripples" through each industry sector. For any given type of change in economic activity, the impacts on the economy can be reported on one of three levels:

1. Direct impacts represent the initial change in final demand for the industry sector(s) in question. Direct impacts describe the changes in economic activity for sectors that first experiences a change in demand because of a project, policy decision, or some other stimuli.

\footnotetext{
28 "Other earnings" includes small business income, corporate profits, and indirect business taxes paid to government.
} 
2. Indirect impacts represent the response as supplying industries increase output in order to accommodate the initial change in final demand. These indirect beneficiaries will then spend money for supplies and services, which results in another round of indirect spending, and so on.

3. Induced impacts are generated by the spending of households who benefit from the additional wages and business income they earn through all of the direct and indirect activity. The increase in income, in effect, increases the purchasing power of households.

The following example illustrates how these types of impacts affect overall economic activity. Suppose that a new manufacturing facility comes to a region. The direct impacts would consist of the value of output produced at the facility, and the number of employees working at the facility and their payroll.

In order to operate, the manufacturing facility will purchase a host of goods and services including, for example, spare parts and equipment, repair services, electricity, water and sewer, etc. This spending generates the first round of indirect impacts. Suppliers and vendors to the manufacturing facility will also have to purchase additional goods and services. The local special trade contractor hired to repair a component on the manufacturing floor will purchase welding equipment and gases, lease equipment, and fuel their vehicles. This spending leads to another round of indirect impacts.

The direct and indirect increases in employment and income enhance the overall purchasing power in the economy. Workers at the manufacturing facility will use their income to purchase groceries or take their family to the theater. Workers at businesses who supply the manufacturing facility will do the same. This spending will generate induced economic impacts for workers and businesses in other sectors of the economy.

This cycle of spending does not go on forever. It continues until the spending eventually leaks out of the local economy as a result of taxes, savings, or purchases of non-locally produced goods and services or "imports". As discussed previously, we can now see how the definition of the study area affects the impact analysis. A larger study area will have greater economic linkages between businesses and institutions, and a smaller propensity to import. As a result, the initial economic stimulus filters throughout the economy more than it would for a smaller study area, and the multipliers are larger than they would be for a smaller study area.

\section{LIMITATIONS OF INPUT-OUTPUT MODELING}

The input-output modeling framework for economic impact analysis has grown in popularity. Much of this growth is due to significant improvements in computer technology that now make it possible to quickly perform the complex matrix operations. Some of this growth is due to improvements in government data collection efforts. Lastly, the growth in input-output modeling has been fueled by the desire of policy makers, industry officials, and others to obtain information that will help them to better understand and respond to economic change.

Like many quantitative tools, input-output models rely on a set of assumptions. Indeed, without simplifying assumptions it would be impossible for researchers to model something as complex and dynamic as a regional economy. The use of simplifying assumptions, however, also imposes certain limitations on the use of input-output modeling. These limitations should be fully understood and guide its use. 


\section{Input-Output Modeling-Static Models}

Input-output models are static models in that they measure the flow of inputs and outputs in an economy at a point in time. With this information and the balanced accounting structure of an input-output model, an analyst can: 1) describe an economy at one time period, 2) introduce a change to the economy, and then 3 ) evaluate the economy after it has fully accommodated that change.

This type of analysis is called "partial equilibrium" analysis. Input-output models are just one of many economic models that fall under the rubric of partial equilibrium analysis. The logic of partial equilibrium analysis is straightforward: take a snapshot of an economy, posit a change to the economy, and then take another snapshot to measure what happened. Measurement in this sense is really a before and after comparison.

Partial equilibrium analysis permits comparison of the economy at two points in time, but yields little information about how the economy actually moves from one equilibrium to the next. In fact, in partial equilibrium analysis, other than the initial economic stimulus, the researcher assumes that all other relationships in the economy remain the same.

Their point-in-time construction and the assumption that nothing else changes, make static input-output models very different than dynamic models. Dynamic models have feedback effects that allow the events of one year to change the linkages in future years. In so doing, dynamic models simulate the expected long-term changes in the structure of the economy. Contrary to dynamic models, static models assume that there are no changes in wage rates, input prices, and property values. In addition, underlying economic relationships in input-output models are assumed constant, i.e., there are no changes in the productivity of labor and capital, and no changes in population migration or business location patterns.

The assumptions and their implications for input-output modeling are discussed below.

\section{Fixed Production Relationships}

Input-output models are a representation - as reported in the transactions table - of economic relationships that exist at a moment in time. For industries, this means that input-output models are based on production relationships that are fixed. This assumption results in:

- Constant Returns to Scale means that an industry's production function is linear, and an increase in output requires all inputs to increase proportionately. If the demand for milk doubled, for instance, then the demand for all of the inputs used to produce milk would also double. In the long run, production processes exhibit economies and diseconomies of scale that vary with the level of output. An industry with scale economies would be able to double production without necessarily doubling all inputs.

- Fixed Commodity Input Structure means that input-output models do not allow changing input prices to affect the production decisions of businesses. Input-output models assume that changes in an economy will affect the output of industries but not the mix of inputs that they use. Using the previous example, dairies respond to the increase demand for milk by simply increasing production of milk. Input-output models, in effect, ignore possible changes in the prices of inputs used to produce milk. Depending on the size of study area and the economic stimulus, an increase in demand for output could cause one or more input prices to increase. If the increase in demand for milk caused the wage of dairy workers to increase, then economic theory suggests that dairy farmers would have an incentive to substitute other inputs for labor. 


\section{No Supply Constraints}

Input-output models show how local industries respond to some initial change in final demand, but assume that supplies of raw materials and intermediate goods are unlimited, i.e., perfectly elastic. Under an assumption of no supply constraints, an industry simply responds to a change in final demand by increasing output, and it increases output by acquiring inputs that are readily available at current prices.

\section{Sector Homogeneity}

An industry consists of businesses producing goods and services - these are called commodities in inputoutput modeling. Businesses can produce more than one type of commodity, i.e., they produce a primary commodity, but can also produce secondary commodities or by-products.

In input-output modeling, industry sectors are assumed to be homogenous. That is, all businesses within an industry sector 1) produce commodities in fixed proportions and 2) produce identical commodities that are perfectly substitutable. Using the previous example, an increase in demand for milk will cause dairy farms to increase production of milk as well as other by-products such as buttermilk, cottage cheese, and sour cream. If the demand for milk doubled causing milk production to double, then the output of byproducts will also double. In addition, dairy farms are assumed to produce milk that is perfectly identical across farms.

\section{Input-Output Modeling-Practical Considerations}

Apart from the limitations imposed by the static nature of input-output models, there are also some very practical considerations that should also guide their use. These practical considerations are discussed below.

\section{Lag Between Data Collection and Modeling}

Input-output models can be constructed for almost any geographic region. Typically, their structure is based on a national input-output model ${ }^{29}$ that is then combined with national and regional economic data to tailor the model to a specific study area. However, there is often a lag between actual data collection and incorporation of that data into the modeling software. With this "implementation" lag, changes in the structure of an economy - such as improvements in technology, changes in demand, and changes in regional trade patterns - will affect the multipliers and make the results less reliable. Obviously, inputoutput models constructed with the most current data available will provide the most accurate results.

\section{Time}

Economic impacts occur over time. As discussed previously, depending on their occurrence, impacts can be categorized as direct, indirect, and induced. These impacts are far from instantaneous. The implications for impact analysis are two-fold.

First, sometimes the effects of a large project can span several decades. The direct hires and payment of wages and benefits will also span that period of time. In this context, the researcher must consider the fact that inflation erodes purchasing power over time. If economic impacts are to be reported accurately, each

\footnotetext{
${ }^{29}$ The U.S. Bureau of Economic Analysis constructs national benchmark input-output accounts every five years. The most current version available is the 1997 benchmark accounts. BEA estimates that the 2002 benchmark accounts will be completed by the summer of 2007 .
} 
dollar needs to be presented in terms of its economic value today. Economists must use a base year when conducting input-output analysis. All transactions that occur after that base year should be discounted by some factor to account for expected changes in the relative value of the dollar.

The inflation assumptions that are built into an input-output analysis can have a profound impact on its results. Underestimating inflation by just one percent will inflate the net present value of a multi-million dollar project by a wide margin.

Second, the indirect and induced impacts take time to filter through the economy. Researchers use economic multipliers calculated in input-output analysis as a mathematical short cut for providing an estimate of final impacts. These final impacts are generated as spending cycles between businesses, consumers, governments and foreigners. This multiplier process takes time.

\section{THE IMPLAN INPUT-OUTPUT MODELING SOFTWARE}

One of the most common software packages used to conduct input-output analyses is IMPLAN (IMpact analysis for PLANning). IMPLAN was developed by the US Forest Service in cooperation with the Federal Emergency Management Agency and the Bureau of Land Management to assist federal agencies in their land and resource management planning. Since 1993, IMPLAN has been maintained and distributed by the Minnesota IMPLAN Group, Inc. ${ }^{30}$ Currently there are over 1,500 public and private users of the IMPLAN modeling software.

Applications of IMPLAN by the US Government, public agencies, and private firms span a wide range of projects. Examples include new factories, resorts, proposals for developing coal mines, and harvesting timber. IMPLAN can also be applied to a variety of policy issues. Predicting the effects of a tourism marketing campaign or measuring the importance of an existing industry on a local community are common examples.

\section{The Structure of the Input-Output Model in IMPLAN}

IMPLAN uses a commodity/industry accounting framework that corresponds closely to that used in the Bureau of Economic Analysis "Input-Output Study of the U.S. Economy," and those recommended by the United Nations.

\section{IMPLAN Database}

IMPLAN uses a large database of regional and national data to forecast economic activity. The main sources of data are:

- US Bureau of Economic Analysis 1997 Benchmark I/O Accounts

- US Bureau of Economic Analysis Output Estimates

- US Bureau of Economic Analysis REIS Program

- US Bureau of Labor Statistics Covered Employment and Wages or ES202 data

- US Bureau of Labor Statistics Consumer Expenditure Survey

- US Census Bureau County Business

- US Census Bureau Decennial Census and Population Surveys

- US Census Bureau Economic Censuses and surveys

\footnotetext{
${ }^{30}$ For additional information, see the Minnesota IMPLAN Group's website at www.implan.com.
} 
- US Department of Agriculture Crop and Livestock Statistics

- US Geological Survey

In IMPLAN, the process that develops county-level input-output models generates coefficients that are internally consistent, in that county data sum to state totals and state data sum to national totals. This generally is not the case with survey-based input-output models, which limits their applicability to largescale projects that affect a number of interrelated regions. ${ }^{31}$

\section{Sectors}

A sector consists of industries that produce similar products or services. IMPLAN breaks an economy down to 509 separate industry sectors based on the North American Industrial Classification System ("NAICS").

\section{Final Demands}

Final demand is sum of all purchases of goods and services for final consumption within an economy. In the IMPLAN model, final demands are in producer prices and are allocated among industry sectors. In addition, final demands are adjusted or "margined" to reflect the transportation, wholesale, and retails costs of getting products from industries to consumers.

The IMPLAN model has the following major categories of final demand:

- Personal Consumption Expenditures. The largest component of final demand comes from household spending. Households consume a wide variety of goods and services, including food, energy, housing, and transportation. They also use some of their personal income to pay taxes, save for the future, pay debts, or purchase new housing. In IMPLAN, households are disaggregated by income levels to account for different spending patterns across income levels.

- Federal Government Purchases. Government purchases are broken down into two categories: military and non-military. Military expenditures include any purchases made in the interest of national defense. Non-military expenditures include all other purchases made by the federal government for the remaining services it provides.

- State and Local Government Purchases. State and local government purchases are also broken down into two categories: education and non-education. Spending on public education goes primarily to compensate teachers, but also includes things like textbooks and supplies. Noneducation spending includes anything not spent for public education such as police, fire and emergency services, and state-sponsored healthcare.

- Inventory Purchases. Inventories accumulate anytime an industry fails to sell all of its output in a given year. Goods can be sold out of inventory any time sales exceed production. Industries rarely sell exactly what they produce each year, so this category is a widely used tool for reconciling economic activities.

\footnotetext{
${ }^{31}$ Arguably, however, an input-output model estimated from survey data has more accurate coefficients, because the survey can be customized to the problem at hand. In contrast, IMPLAN derives its coefficients using a combination of the national inputoutput survey model and local activity data; conceivably, this will produce somewhat different results from a direct, local survey. Given the difficulty and expense of input-output surveys, however, the disadvantages of the IMPLAN approach are slight.
} 
- Capital Formation. A large component of productive capability is capital. Industries use varying quantities of capital depending on the nature of goods and services they provide. The manufacturing sector, for example, tends to require large investments in property, plant, and equipment for the goods it produces. This category of final demand contains all spending on capital equipment.

- Foreign Exports. Just as some economies must import goods and services from outside their borders, other economies sell a significant portion of their output overseas. Demand for final goods and services that come from beyond a region's borders falls into this category. Although the consumption happens elsewhere, input-output analysis is concerned with where the goods and services are produced.

\section{Types of impacts}

IMPLAN reports economic impacts as measured by changes in output, incomes (value added), jobs and taxes. The value added or income measure is broken out into four categories. These measures of economic impacts consist are:

- Output: The total value of the production of a sector is its output. For most sectors, output approximately equal to sales. The notable exceptions are government and the trade sectors. The output of government sectors is approximately equal to revenues. For the trade sector, which consists of firms that buy goods and re-sell them, output is roughly the difference between what they sell goods for and what they paid to procure them. The trade sector consists of wholesalers and retailers.

- Value Added: This is a measure of the value added to the economy by a sector. It equals the sum of the wages, proprietor income, other income, and indirect business taxes.

- Wages represent the total cash and non-cash compensation of workers on payroll. This includes the value of benefits.

- Proprietor Income, sometimes called small business income, is the amount earned by selfemployed workers and the working owners of small businesses.

- Other Income counts all other sources of income. The largest source of income is usually rents, but it may also include royalties, dividends, and corporate profits.

- Indirect business taxes are the excise and sales taxes paid by individuals to businesses.

- Employment: The total number of payroll employees, including part time workers. The selfemployed are not counted, however, their earnings are captured under proprietor income.

- Taxes: Total Federal, state, and local tax revenues.

\section{Modeling}

The process of modeling in IMPLAN involves three steps:

1. Creation of study area database;

2. Customization of IMPLAN coefficients; and

3. Estimating the impact of an activity on the model of the study area economy. 
The IMPLAN model allows substitution and incorporation of primary data at each stage of the modelbuilding process, greatly increasing the model's accuracy and flexibility. In addition to being able to directly modify the IMPLAN database statistics, the user can alter import and export relationships, utilize modified input-output functions, and change industry groupings. IMPLAN allows the creation of aggregate models consisting of industries grouped together for a specific purpose.

The key to input-output analysis is the construction of the input-output or transactions table, which shows the flow of commodities from each of a number of producing industries to all consuming industries and final demand (ultimate consumers). Given that many industries produce more than one commodity, production information is often tabulated on an industry-by-commodity basis into a "Make" matrix, containing the value of commodities produced by different industries, and a "Use" matrix, containing the value of commodities used by each industry in the production process. These matrices are combined to produce the input-output transactions table showing each industry buying and selling from other industries.

From these industry flows, two other structural tables are developed: (1) a table of technical coefficients or direct requirements and (2) a table of direct and indirect coefficients or total requirements. The entries in the former are interpreted as the dollar value of the minimal requirements from each of the contributing industries in order for each producing industry to produce one dollar's worth of output. The entries in the latter table are to be interpreted as the amount of output from the contributing industries required, both directly and indirectly, to deliver one dollar's worth of the producing industry's output to final demand.

\section{Customizing the IMPLAN Coefficients}

The process of customizing the IMPLAN model does not stop with the development of the study area databases. Part of the expertise of input-output practitioners is in the customization of the model coefficients. Depending on the type of analysis, this enables the analyst to:

- Vary structural, technological, and/or trade factors within the model. For instance, the user may add or remove sectors from the model, or change the size of an industry, or the user may change production functions, or make changes in commodity imports and exports.

- Exclude expenditures that do not generate current economic activity, such as depreciation and amortization.

- Exclude expenditures that are known to occur outside the local economy. The IMPLAN model contains purchasing assumptions ${ }^{32}$ for each industry sector that are specific to the study area. Instead of relying entirely on these purchasing assumptions, the analyst can identify and remove spending that is known to occur outside of local economy.

The IMPLAN system permits a sector-by-sector breakout of transportation, wholesale, and retail margins, and allows the user to over-ride these margin assumptions using primary source data if available. For instance, instead of the estimated retail margin embedded in the IMPLAN model, the analyst can use actual retail margins for the activity.

\footnotetext{
32 These purchasing assumptions are called "Regional Purchase Coefficients." They specify the ability of local suppliers to meet or satisfy a change in demand for a good or service.
} 


\section{Estimating Multipliers}

The last step in building the model is to estimate the multipliers. Multiplier analysis is used to estimate the regional economic impacts resulting from a change in final demand. Impacts can be in terms of direct and indirect effects (commonly known as Type I multipliers), or in terms of direct, indirect, and induced effects (Type II and Type III multipliers).

More specifically, direct effects are production changes associated with the immediate effects of final demand changes. Indirect effects are production changes in backward-linked industries caused by the changing input needs of directly affected industries. Induced effects are the changes in regional household spending patterns caused by changes in household income - generated from the direct and indirect effects.

IMPLAN calculates two types of multipliers for each of the five impact measures. The first output multiplier represents the value of production, from indirect and direct effects, required from all sectors by a particular sector in order to deliver one dollar's worth of output. The second output multiplier adds in the induced requirements. The size of the multiplier is not a measure of the amount of activity or the importance of a given industry for the economy. It is an estimation of what would happen if that industry's sales to final demand increased or decreased. In other words, output multipliers can be used to gauge the interdependence of sectors; the larger the output multiplier, the greater the interdependence of the sector on the rest of the regional economy.

\section{Performing Impact Analysis}

Once the input-output model is built, impact analysis can be performed on the model. There are two general types of impact analysis. At a very simple level, an analyst can evaluate economic changes using industry sectors contained in the IMPLAN model. In this case, business revenues or employment are used to model changes in demand in the relevant industry sector.

In some cases, such as the entry of a new business, the industry sector may not be represented in the IMPLAN model of that region. This type of analysis is more complicated and requires the use of expenditure and revenue data to develop a spending pattern (or "production function") that is specific to the activity. Under this type of analysis:

- The direct effects are based on output, employment and personal income data supplied by the client.

- The indirect effects are measured by identifying changes in output for each industry from which goods and services are purchased. What is specified as direct impacts in this model are more precisely described as the first round of indirect impacts. Subsequent rounds of indirect impacts occur as vendors and suppliers purchase goods and services from other businesses, who will also need to buy goods and services. The indirect impacts of the activity are what the IMPLAN model reports as direct and indirect impacts in this model.

- The induced impacts are based, in part, on estimates of the direct personal income generated in production. This data is fed into a consumption function specific for that household income group and region. What is specified as direct impacts in this model are actually the first round of induced impacts, so what is reported as induced impacts are the total impacts from this model plus the induced impacts from the model inter-industry expenditures.

The IMPLAN model is perhaps the most popular input-output modeling system in use today. Of course, any software is susceptible to the "garbage in—garbage out" phenomenon. Thus, the accuracy of its 
results is dependent on the quality of the data used in the modeling process as well as the skills of the analyst in conducting the analysis. 


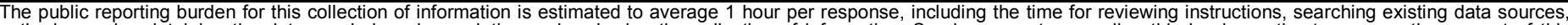

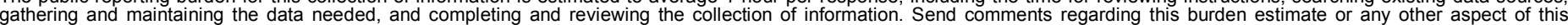

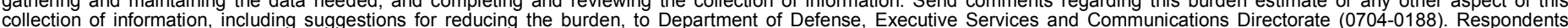

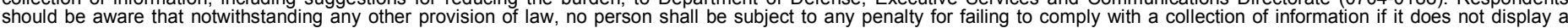

should be aware that notwithstanding

PLEASE DO NOT RETURN YOUR FORM TO THE ABOVE ORGANIZATION.

\section{REPORT DATE (DD-MM-YYYY) \\ August 2007 \\ 2. REPORT TYPE \\ Subcontract Report}

4. TITLE AND SUBTITLE

Energy, Economic, and Environmental Benefits of the Solar America Initiative
3. DATES COVERED (From - To) 5a. CONTRACT NUMBER

DE-AC36-99-GO10337

5b. GRANT NUMBER

5c. PROGRAM ELEMENT NUMBER

5d. PROJECT NUMBER

NREL/SR-640-41998

5e. TASK NUMBER

PVB7.6301

5f. WORK UNIT NUMBER

\section{PERFORMING ORGANIZATION NAME(S) AND ADDRESS(ES)}

ECONorthwest

888 SW Fifth Ave., Suite 1460

Portland, OR 97204

9. SPONSORING/MONITORING AGENCY NAME(S) AND ADDRESS(ES)

National Renewable Energy Laboratory

1617 Cole Blvd.

Golden, CO 80401-3393
8. PERFORMING ORGANIZATION REPORT NUMBER

ADJ-7-77253-01
10. SPONSOR/MONITOR'S ACRONYM(S) NREL

11. SPONSORING/MONITORING AGENCY REPORT NUMBER NREL/SR-640-41998

12. DISTRIBUTION AVAILABILITY STATEMENT

National Technical Information Service

U.S. Department of Commerce

5285 Port Royal Road

Springfield, VA 22161

13. SUPPLEMENTARY NOTES

NREL Technical Monitor: R. Margolis

14. ABSTRACT (Maximum 200 Words)

The President's Solar America Initiative (SAI) was launched in January 2006 as part of the administration's Advanced Energy Initiative. The SAI is being led by the U.S. Department of Energy (DOE) Solar Energy Technologies Program (SETP), with NREL providing analytical and technical support. The SAI has a goal of installing 5-10 GW of photovoltaic (PV) systems in the United States by 2015 and 70-100 GW of PV systems in the United States by 2030. To make PV cost-competitive with other energy resources, this requires that the installed cost of PV fall from approximately $\$ 8 / \mathrm{Wdc}$ in 2005 to $\$ 3.3 / \mathrm{Wdc}$ in 2015 and $\$ 2.5 / \mathrm{Wdc}$ in 2030 . This report presents estimates of the potential energy, economic, and environmental benefits that could result should the SAI PV installation goals be achieved.

\section{SUBJECT TERMS}

NREL; Solar America Initiative; SAI; Advanced Energy Initiative; Solar Energy Technologies Program; photovoltaics; $\mathrm{PV}$; energy benefits; environmental benefits; economic benefits

16. SECURITY CLASSIFICATION OF:
\begin{tabular}{|l|l|l|}
\hline a. REPORT & b. ABSTRACT & c. THIS PAGE \\
Unclassified & Unclassified & Unclassified \\
& & \\
\hline
\end{tabular}

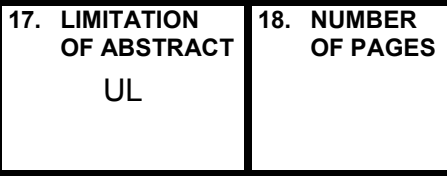

19a. NAME OF RESPONSIBLE PERSON

19b. TELEPHONE NUMBER (Include area code) 